\title{
Mitocryptide-2: Identification of Its Minimum Structure for Specific Activation of FPR2-Possible Receptor Switching from FPR2 to FPR1 by Its Physiological C-terminal Cleavages
}

\author{
Takayuki Marutani $^{\dagger}{ }^{,}$Kodai Nishino, Tomoyuki Miyaji, Keisuke Kamada, Koji Ohura, Yoshiaki Kiso \\ and Hidehito Mukai *D
}

check for updates

Citation: Marutani, T.; Nishino, K.; Miyaji, T.; Kamada, K.; Ohura, K.; Kiso, Y.; Mukai, H. Mitocryptide-2: Identification of Its Minimum Structure for Specific Activation of FPR2-Possible Receptor Switching from FPR2 to FPR1 by Its Physiological C-terminal Cleavages Int. J. Mol. Sci. 2021, 22, 4084

https://doi.org/

10.3390/ijms22084084

Academic Editor: Andrey

V. Kuznetsov

Received: 2 March 2021

Accepted: 12 April 2021

Published: 15 April 2021

Publisher's Note: MDPI stays neutral with regard to jurisdictional claims in published maps and institutional affiliations.

Copyright: (c) 2021 by the authors. Licensee MDPI, Basel, Switzerland. This article is an open access article distributed under the terms and conditions of the Creative Commons Attribution (CC BY) license (https:/ / creativecommons.org/licenses/by/ $4.0 /)$.
Laboratory of Peptide Science, Graduate School of Bio-Science, Nagahama Institute of Bio-Science and Technology, Nagahama, Shiga 526-0829, Japan; b210052@nagahama-i-bio.ac.jp (T.M.); b112116@m.nagahama-i-bio.ac.jp (K.N.); b116169@m.nagahama-i-bio.ac.jp (T.M.); b116046@m.nagahama-i-bio.ac.jp (K.K.); b116028@m.nagahama-i-bio.ac.jp (K.O.); y_kiso@nagahama-i-bio.ac.jp (Y.K.)

* Correspondence: hmukai-endo@umin.ac.jp; Tel.: +81-749-64-8113

+ Supported by JSPS Research Fellowship for Young Scientists.

\begin{abstract}
Mitocryptides are a novel family of endogenous neutrophil-activating peptides originating from various mitochondrial proteins. Mitocryptide-2 (MCT-2) is one of such neutrophil-activating peptides, and is produced as an $\mathrm{N}$-formylated pentadecapeptide from mitochondrial cytochrome $b$. Although MCT-2 is a specific endogenous ligand for formyl peptide receptor 2 (FPR2), the chemical structure within MCT-2 that is responsible for FPR2 activation is still obscure. Here, we demonstrate that the N-terminal heptapeptide structure of MCT-2 with an $\mathrm{N}$-formyl group is the minimum structure that specifically activates FPR2. Moreover, the receptor molecule for MCT-2 is suggested to be shifted from FPR2 to its homolog formyl peptide receptor 1 (FPR1) by the physiological cleavages of its C-terminus. Indeed, N-terminal derivatives of MCT-2 with seven amino acid residues or longer caused an increase of intracellular free $\mathrm{Ca}^{2+}$ concentration in HEK-293 cells expressing FPR2, but not in those expressing FPR1. Those MCT-2 derivatives also induced $\beta$-hexosaminidase secretion in neutrophilic/granulocytic differentiated HL-60 cells via FPR2 activation. In contrast, MCT-2(1-4), an N-terminal tetrapeptide of MCT-2, specifically activated FPR1 to promote those functions. Moreover, MCT-2 was degraded in serum to produce MCT-2(1-4) over time. These findings suggest that MCT-2 is a novel critical factor that not only initiates innate immunity via the specific activation of FPR2, but also promotes delayed responses by the activation of FPR1, which may include resolution and tissue regeneration. The present results also strongly support the necessity of considering the exact chemical structures of activating factors for the investigation of innate immune responses.
\end{abstract}

Keywords: cryptide; mitocryptide; N-formylated peptide; neutrophil; formyl peptide receptor 1 ; formyl peptide receptor 2; inflammation

\section{Introduction}

Neutrophils are a type of leukocyte that are involved in the innate defense system [1-3]. Neutrophils comprise the majority of peripheral leukocytes and normally exist in the bloodstream to monitor for infection and tissue damage. When tissue injury occurs due to bacterial infections or internal tissue damage, neutrophils immediately migrate to and infiltrate the injury site. The infiltrated neutrophils are then activated and exert their functions, including superoxide production and phagocytosis of invading bacterial components and toxic substances.

Bacterial N-formylated proteins and peptides, including formyl-Met-Leu-Phe (fMLF) [4,5], complement related factors such as component 5a [6,7], and some chemokines such as IL-8 $[8,9]$ chemoattract and activate neutrophils to promote inflammatory reactions. Moreover, various mitochondrial-derived peptides that also activate neutrophils were recently 
identified in mammalian tissues [10-14]. Namely, we isolated and identified the novel neutrophil-activating peptides mitocryptide-1, mitocryptide-2 (MCT-2), and mitocryptideCYC, which are cleaved from mitochondrial cytochrome c oxidase subunit VIII, cytochrome $b$, and cytochrome $c$, respectively, from porcine heart [10-13]. In addition, we found the possible presence of many mitocryptides that were derived from various mitochondrial proteins to induce the migration and activation of neutrophils $[10,14]$.

Recently, there has also been interest in the roles of mitochondria and their derived substances in innate immunity. Indeed, various tissues damaged by trauma or burns release mitochondria and their contents into the bloodstream [15-21]. Mitochondria and their contents are also released from a variety of cells damaged by bacterial infection [21-25]. In addition, it is suggested that mitochondria and their derived substances are leaked into the cerebrospinal fluid from damaged tissues in patients with Alzheimer's disease $[26,27]$. These released mitochondria and their derived factors, which are called mitochondrial damage-associated molecular patterns (mtDAMPs), promote various innate immune responses, including induction of neutrophil and macrophage migration and activation $[15,17,21,28,29]$. MtDAMPs also stimulate the secretion of inflammatory mediators from mast cells [30].

$\mathrm{N}$-formylated peptides may constitute one family of the activating factors in $\mathrm{mt}-$ DAMPs because inhibitors against the functions of $\mathrm{N}$-formylated peptides prevent the activity of mtDAMPs $[15,17,28]$. Specifically, as 13 proteins are encoded in mitochondrial DNA and are translated in mitochondria as $\mathrm{N}$-formylated forms [31,32], these proteinderived $\mathrm{N}$-formylated peptides may exist in mtDAMPs, and are thought to cause proinflammatory responses including neutrophil infiltration and activation. As MCT-2 is the only endogenous $\mathrm{N}$-formylated peptide that has been isolated from mammalian tissues so far and its complete chemical structure has been determined, it is a leading candidate for such activating factors in mtDAMPs.

Formyl peptide receptor 1 (FPR1, formerly referred to as formyl peptide receptor) and formyl peptide receptor 2 (FPR2, formerly referred to as formyl peptide receptorlike 1) recognize not only $\mathrm{N}$-formylated proteins and peptides derived from bacteria but also endogenous $\mathrm{N}$-formylated peptide MCT-2 and putative peptides derived from mitochondrial $\mathrm{N}$-formylated proteins [33-38]. These receptors are expressed mainly by inflammatory immune cells such as neutrophils and macrophages, and their activation induces not only the infiltration of neutrophils and macrophages into injury sites but also the phagocytosis of toxic debris, superoxide generation, and the production of inflammatory cytokines $[35,37,38]$. FPR2 is also expressed by endothelial cells, and its activation causes an increase in vascular permeability to promote further neutrophil infiltration from the bloodstream to injury sites during the initial stage of inflammation [38,39]. Moreover, FPR1 is proposed to be involved in the processes of resolution and wound healing/tissue regeneration. Indeed, FPR1 activation induces the proliferation of various cells, including epithelial cells and hepatocytes, to promote tissue regeneration [40-44]. In this way, FPR1 and FPR2 are thought to participate throughout the initiation of the proinflammatory response by tissue damage, healing, and regeneration.

However, it is unknown how FPR2 and FPR1 recognize various endogenous Nformylated peptides, including MCT-2. FPR2 specifically recognizes MCT-2 and its Nterminal derivatives longer than ten amino acid residues to activate neutrophils $[36,45]$. Putative endogenous $\mathrm{N}$-formylated peptides derived from mitochondrial DNA-encoded proteins activate FPR2 and/or FPR1, i.e., NADH dehydrogenase subunit 4(1-20) and NADH dehydrogenase subunit 5(1-28) specifically activate FPR2, whereas NADH dehydrogenase subunit 6(1-6) specifically activates FPR1, and cytochrome $c$ oxidase subunit I(1-13) activates FPR1 and FPR2 [46]. However, the chemical structure within endogenous $\mathrm{N}$-formylated peptide MCT-2 that is specifically recognized by FPR 2 as well as those within endogenous N-formylated peptides recognized by FPR1 or FPR2 are unclear, although the $\mathrm{N}$-formyl group of those peptides is known to be essential for recognition by FPR 2 and FPR1 [45]. 
In this study, we investigated the structure-activity relationships of MCT-2 and its derivatives to elucidate how FPR2 recognizes MCT-2. We also explored the time-dependent alterations of the molecular forms of MCT-2 in serum and attempted to elucidate the meaning of these alterations in innate immune responses.

\section{Results}

2.1. Effects of MCT-2(1-15) and Its Derivatives on $\left[\mathrm{Ca}^{2+}\right]_{i}$ in HEK-293 Cells Stably Expressing FPR1 or FPR2

An endogenous pentadecapeptide, MCT-2 [MCT-2(1-15)], specifically binds to and activates FPR2, but it neither interacts with nor activates FPR1 [36]. In addition, MCT-2(1-10) or $\mathrm{N}$-terminal derivatives longer than it specifically activate FPR 2 to cause $\beta$-arrestin recruitment and superoxide production [45]. However, the precise structure within MCT-2(1-15) that is responsible for the specific activation of FPR2 is not known. Here, increases in the concentration of intracellular free $\mathrm{Ca}^{2+}\left(\left[\mathrm{Ca}^{2+}\right]_{\mathrm{i}}\right)$ promoted by MCT-2(1-15) and its derivatives were assessed in HEK-293 cells stably expressing FPR1 or FPR2 (Figure 1). The G $\alpha_{16}$ type of $G$ protein was also stably co-expressed in these cells because this protein interacts with various $G$ protein-coupled receptors and effectively induces an agonist-promoted increase of $\left[\mathrm{Ca}^{2+}\right]_{\mathrm{i}}[47]$. As a result, $100 \mu \mathrm{M}$ MCT-2(1-10), MCT-2(1-9), MCT-2(1-8), and MCT-2(1-7) as well as $10 \mu \mathrm{M}$ MCT-2(1-15) induced an increase of $\left[\mathrm{Ca}^{2+}\right]_{i}$ in HEK-293 cells expressing FPR2, but not in FPR1-expressing cells (Figure 1A-E). In contrast, $100 \mu \mathrm{M}$ MCT-2(1-5) induced an increase of $\left[\mathrm{Ca}^{2+}\right]_{\mathrm{i}}$ in FPR1- and FPR2-expressing cells (Figure 1F). Moreover, $100 \mu \mathrm{M}$ MCT-2(1-4) promoted an increase of $\left[\mathrm{Ca}^{2+}\right]_{\mathrm{i}}$ in FPR1-expressing cells, but not in FPR2-expressing cells (Figure 1G). In addition, stimulation with MCT-2(1-6) did not induce an increase of $\left[\mathrm{Ca}^{2+}\right]_{i}$ in FPR2- or FPR1-expressing cells, even at a concentration of $100 \mu \mathrm{M}$ (data not shown). These results demonstrate that the N-terminal derivative MCT2(1-7) and its longer derivatives specifically activate FPR2, in contrast with MCT-2(1-4), which specifically activates FPR1.

2.2. Effects of C- or N-Terminal Truncations of MCT-2(1-15) on $\beta$-Hexosaminidase Release from Neutrophilic/Granulocytic Differentiated HL-60 Cells

The effects of $\mathrm{N}$ - or C-terminal truncations of MCT-2 on $\beta$-hexosaminidase released from neutrophilic/granulocytic differentiated HL-60 cells were investigated to elucidate the minimum structure that was required for the activation of their receptor molecules. As we reported previously [12,14], a pentadecapeptide MCT-2 [MCT-2(1-15)] dose-dependently promoted $\beta$-hexosaminidase secretion from differentiated HL-60 cells $\left(E_{50}: 20 \pm 7 \mathrm{nM}\right.$, Figure 2 and Table 1), and the maximum response was observed at concentrations greater than $1 \mu \mathrm{M}$.

To elucidate the necessity of the $\mathrm{N}$-formyl group for this stimulation, we examined the effects of its removal from MCT-2(1-15). Des-N-formyl MCT-2(1-15) did not induce $\beta$-hexosaminidase release, even at a concentration of $100 \mu \mathrm{M}$ (Figure 2A), demonstrating that the formyl group at the N-terminus of MCT-2(1-15) is crucial for this process.

Next, we examined the importance of the C-terminal sequence of MCT-2(1-15) for the stimulation of $\beta$-hexosaminidase release from differentiated HL-60 cells by performing C-terminal truncations. Truncations of one to eight amino acid residues from the Cterminus of MCT-2(1-15) caused consecutive increases in the $\mathrm{EC}_{50}$ values without affecting the maximum response. Specifically, the $\mathrm{EC}_{50}$ value of MCT-2(1-14) was increased by approximately five-fold compared with that of MCT-2(1-15) (Figure 2B and Table 1). MCT-2(1-13) and MCT-2(1-12) also exhibited decreased activity when compared with MCT-2(1-15), but MCT-2(1-11) had almost the same potency as MCT-2(1-12) (Figure 2B and Table 1). In addition, the activities of MCT-2(1-10), MCT-2(1-9), and MCT-2(1-8) were sequentially attenuated compared with that of MCT-2(1-11), but with the same maximum effect as MCT-2(1-15), and MCT-2(1-7) had almost the same potency as MCT$2(1-8)$. However, MCT-2(1-6), a derivative that was truncated by nine C-terminal amino acid residues, exhibited a significant decrease of the maximum response compared with 
MCT-2(1-15) (maximum response: $90 \pm 3 \%$ ) with a 5.7-fold increase in the $\mathrm{EC}_{50}$ value compared with MCT-2(1-7). These results indicate that MCT-2(1-7) with an N-formyl group is the minimum structure that is required for maximum stimulation via the activation of FPR2 because the minimum sequence that gave the same level of maximum response as MCT-2(1-15) was MCT-2(1-7), which was also the minimum structure for inducing specific FPR2 activation to cause an increase of $\left[\mathrm{Ca}^{2+}\right]_{\mathrm{i}}$ (Figure 1). In addition, the MCT-2(8-15) structure within MCT-2(1-15) may contribute to the binding affinity between MCT-2(1-15) and FPR2, since the removal of one to eight amino acid residues from the C-terminus did not affect the maximum response, but caused a consecutive increase in $\mathrm{EC}_{50}$ values (Figure 2B and Table 1).

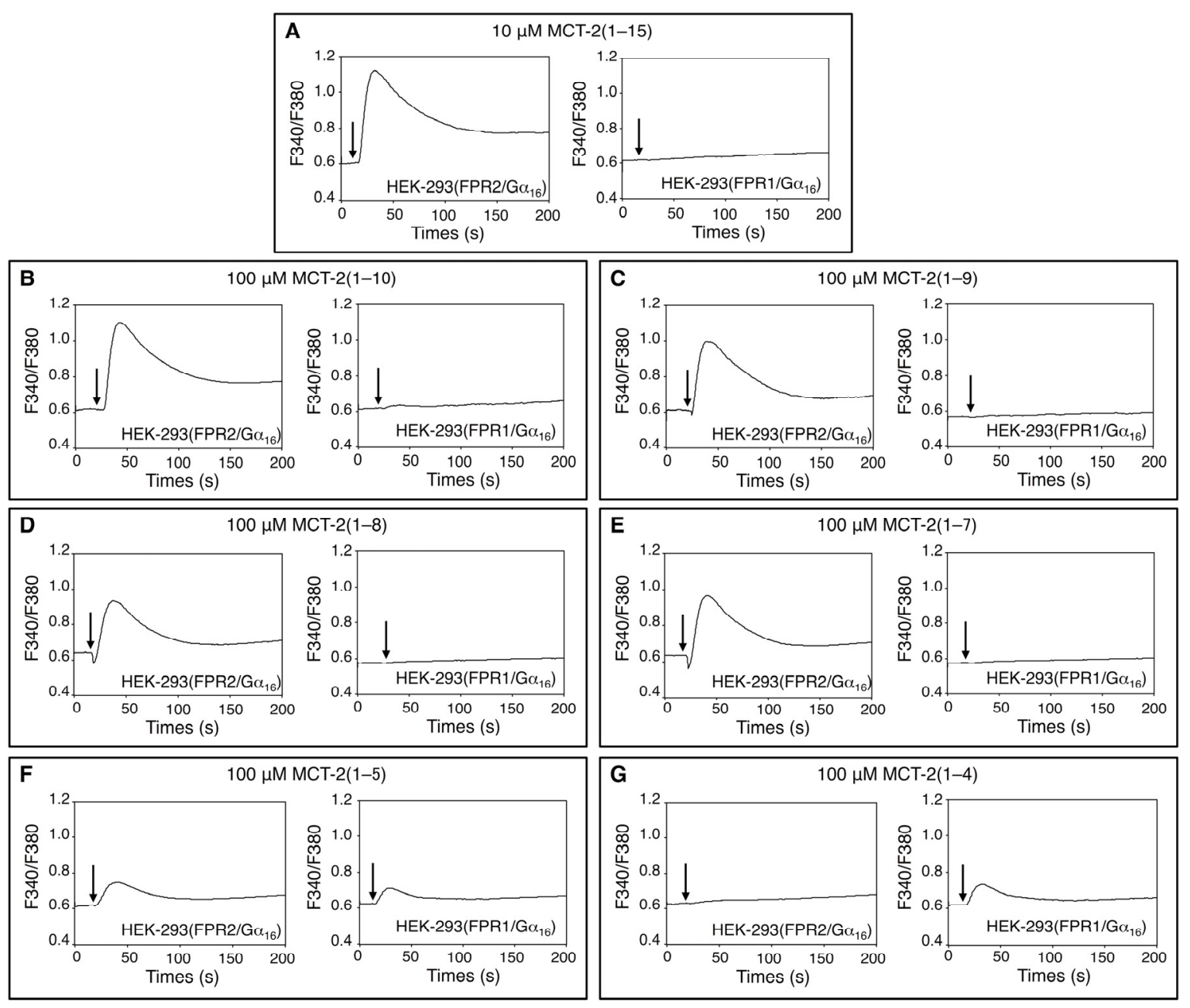

Figure 1. Changes in $\left[\mathrm{Ca}^{2+}\right]_{\mathrm{i}}$ in HEK-293 cells stably expressing FPR1 (formyl peptide receptor 1) or FPR2 (formyl peptide receptor 2) induced by MCT-2 (Mitocryptide-2)(1-15) and its derivatives. Fura-2-loaded cells were stimulated with 10 $\mu \mathrm{M}$ MCT-2(1-15) (A) or $100 \mu \mathrm{M}$ MCT-2(1-10) (B), MCT-2(1-9) (C), MCT-2(1-8) (D), MCT-2(1-7) (E), MCT-2(1-5) (F), and MCT-2(1-4) (G). The changes in the fluorescence ratio of Fura-2 (excitation wavelengths, $340 \mathrm{~nm}$ and $380 \mathrm{~nm}$; emission wavelength, $500 \mathrm{~nm}$ ) were recorded by a fluorometer CAF-100. Horizontal axes show the times after stimulation. Vertical axes depict the fluorescence ratios at excitation wavelengths of $340 \mathrm{~nm}$ and $380 \mathrm{~nm}$. Arrows indicate the timing of peptide administration. 

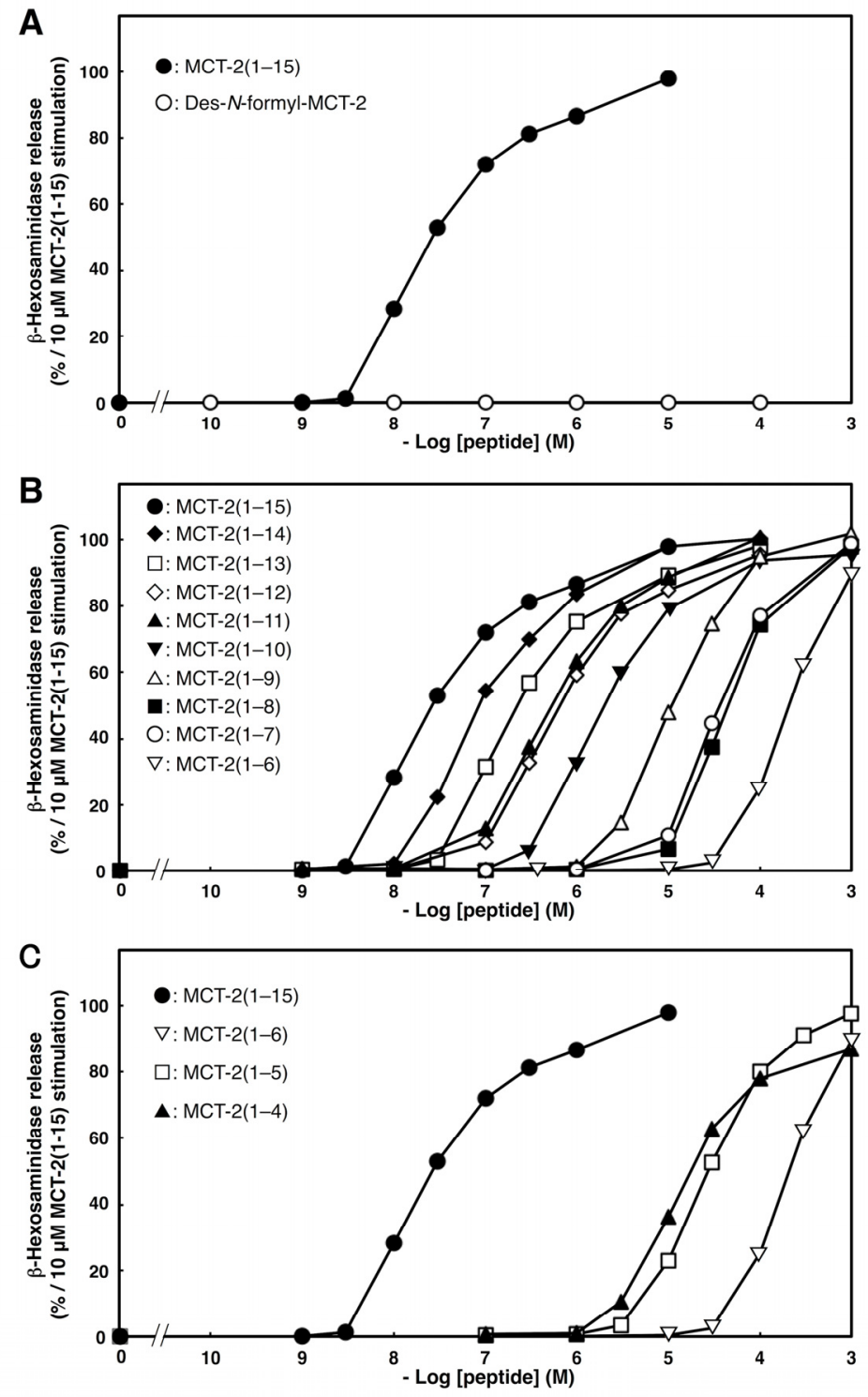

Figure 2. Effects of N-terminal (A) or C-terminal (B,C) truncations of MCT-2(1-15) on $\beta$ hexosaminidase release by differentiated HL-60 cells. The differentiated HL-60 cells were stimulated by MCT-2(1-15) or its derivatives at $37{ }^{\circ} \mathrm{C}$ for $10 \mathrm{~min}$, and the amount of the released $\beta$-hexosaminidase was quantified as described in "Materials and Methods". The ability of each peptide to induce $\beta$-hexosaminidase release is expressed as a percentage of enzyme secretion promoted by $10 \mu \mathrm{M}$ MCT-2(1-15). Data are expressed as the mean $\pm \mathrm{SE}$ of four to six independent experiments.

The effect of C-terminal truncation was examined further because MCT-2(1-6) could still induce $\beta$-hexosaminidase release. As a result, MCT-2(1-5), surprisingly, had 6.5-fold higher activity than MCT-2(1-6) (Figure 2C and Table 1) with the same level of maximum response as MCT-2(1-15). Moreover, the activity of MCT-2(1-4) was further reinforced compared with MCT-2(1-5) as well as MCT-2(1-6) (Table 1); nevertheless, the maximum response of MCT-2(1-4) was significantly reduced by approximately $10 \%$ compared with MCT-2(1-15). Taken together with the observations that MCT-2(1-5) induced the activation of FPR2 and FPR1, and MCT-2(1-4) specifically activated FPR1 for the increases in $\left[\mathrm{Ca}^{2+}\right]_{\mathrm{i}}$ described above (Figure 1), these findings suggest that MCT-2(1-5) effectively promotes the stimulation of $\beta$-hexosaminidase release via FPR1 and FPR2 activation. Furthermore, MCT-2(1-4) specifically activates FPR1 to promote stimulation. 
Table 1. Amino acid sequences of MCT-2(1-15) and its C-terminal or N-terminal derivatives and their EC 50 values and maximum effects on the stimulation of $\beta$-hexosaminidase release from differentiated HL-60 cells.

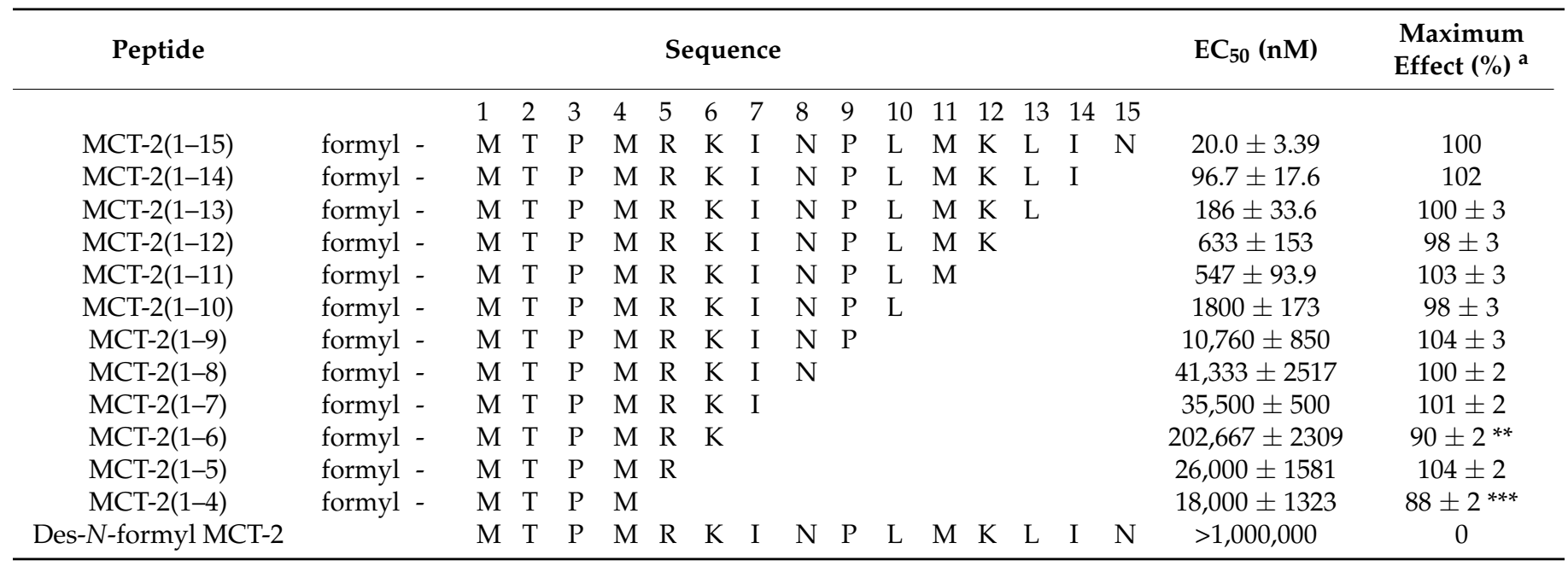

${ }^{a}$ The ability of each peptide to cause $\beta$-hexosaminidase release is expressed as a percentage of enzyme secretion promoted by $10 \mu \mathrm{M}$ MCT-2(1-15). Data are expressed as the mean \pm SE of four to six independent experiments. ${ }^{* *} p<0.01 ;{ }^{* * *} p<0.001$, values significantly different from MCT-2(1-15).

\subsection{Involvement of FPR1 and FPR2 in $\beta$-Hexosaminidase Release Stimulated by MCT-2(1-15)} and Its Derivatives

To further elucidate the involvement of FPR1 and FPR2 in $\beta$-hexosaminidase release from differentiated HL-60 cells stimulated with MCT-2(1-15) and its derivatives, we examined the inhibitory effects of inhibitors against FPR1 [cyclosporin $\mathrm{H}(\mathrm{CysH})$ ] and FPR2 (PBP10) on this process. Stimulation with MCT-2(1-15) at $40 \mathrm{nM}$, which induced approximately $60 \%$ of the maximum response, was dose-dependently inhibited by PBP10, and 1 $\mu \mathrm{M}$ PBP10 completely inhibited this activity, but $1 \mu \mathrm{M}$ CysH did not influence MCT-2(1-15)induced enzyme release (Figure 3A,B). Similarly, the responses induced by MCT-2(1-10), MCT-2(1-9), MCT-2(1-8), and MCT-2(1-7) at a concentration that caused a $60 \%$ response of the maximum effect were also abolished in a dose-dependent manner by PBP10 but not CysH (Figure 3A,B). In contrast, stimulation with MCT-2(1-6) and MCT-2(1-5) was partially inhibited by CysH or PBP10, and the combination of inhibitors $(1 \mu \mathrm{M} \mathrm{CysH}$ and $1 \mu \mathrm{M}$ PBP10) almost completely prevented these responses (Figure $3 \mathrm{C}$ ). Moreover, $\beta$ hexosaminidase release induced by MCT-2(1-4) was completely abolished by $1 \mu \mathrm{M} \mathrm{CysH}$, but was unaffected by $1 \mu \mathrm{M}$ PBP10 (Figure 3A,B). These results also support the notion that MCT-2(1-7) and its longer N-terminal derivatives induce $\beta$-hexosaminidase release from differentiated HL-60 cells via the specific activation of FPR2; in contrast, MCT-2(1-4) specifically activates FPR1, and MCT-2(1-6) and MCT-2(1-5) activate both FPR1 and FPR2 (Figure 3D). 
A
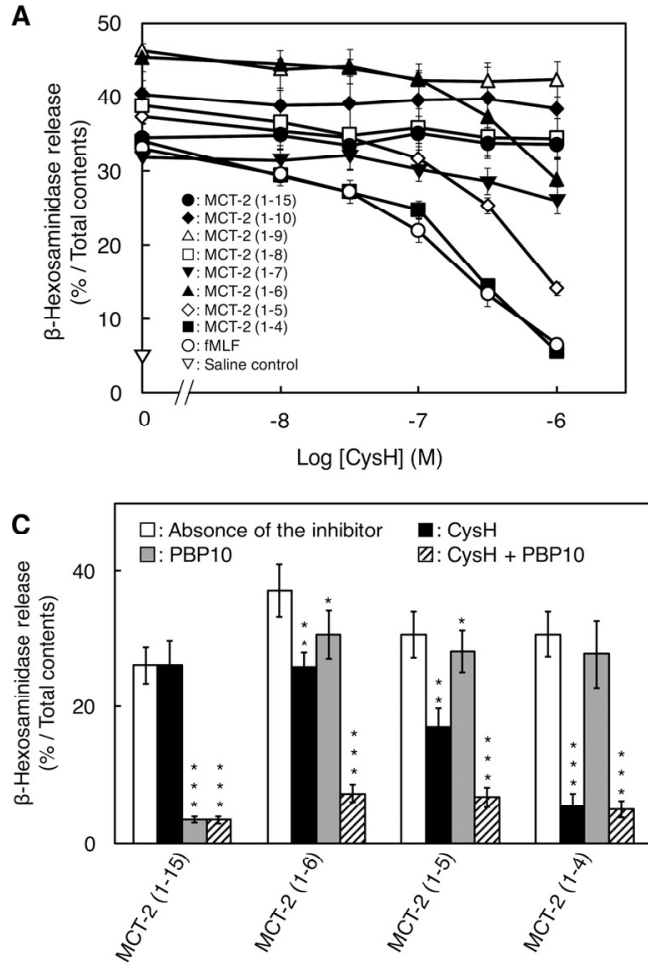

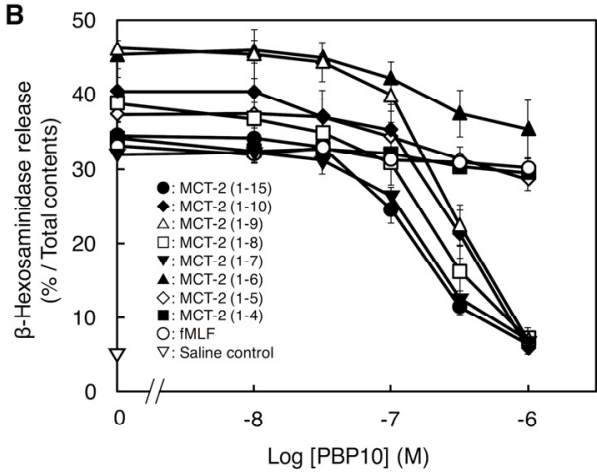

D

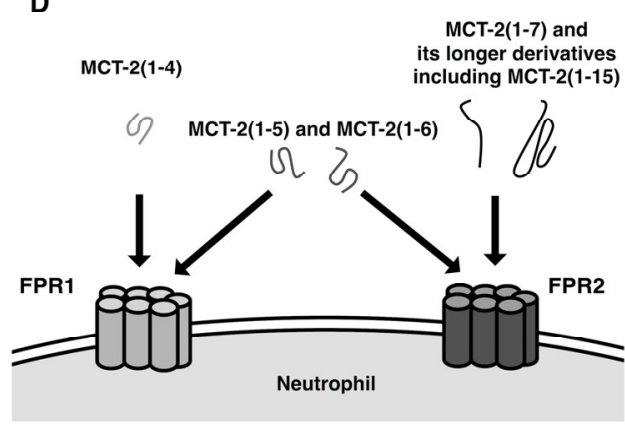

Figure 3. Involvement of FPR1 and FPR2 in $\beta$-hexosaminidase release by differentiated HL-60 cells stimulated with MCT-2(1-15) and its derivatives. (A,B) Concentration-dependent inhibitory effects of inhibitors against FPR1 (CysH) (A) or FPR2 (PBP10) (B) on $\beta$-hexosaminidase release induced by MCT-2(1-15) and its derivatives. (C) Inhibitory effects of CysH (1 $\mu \mathrm{M}$; black), PBP10 (1 $\mathrm{MM}$; gray), or a combination of both inhibitors (1 $\mu \mathrm{M}$ PBP10 and $1 \mu \mathrm{M}$ CysH; slash lines) on the stimulation of $\beta$-hexosaminidase release by MCT-2(1-15) and its derivatives. White bars indicate the stimulation of MCT-2(1-15) and its derivatives in the absence of the inhibitor. The stimulatory concentrations of MCT-2(1-15) and its derivatives were the concentrations that caused a $60 \%$ response of the maximum effect. The ability of each peptide in the absence or the presence of the inhibitors was expressed as a percentage of the total enzyme activity, which was the enzyme activity leaked after disruption of the cells with $0.05 \%$ Triton X-100 (\%/Total). Data are expressed as the mean \pm SE of four to six independent experiments. ${ }^{*} p<0.05$, values significantly different from each peptide in the absence of the inhibitors. (D) Receptor preference of MCT-2(1-15) and its derivatives. N-terminal derivatives of MCT-2 with seven amino acid residues [MCT-2(1-7)] or longer than it specifically activate FPR2, whereas MCT-2(1-4) induces the specific activation of FPR1, as well as MCT-2(1-6) and MCT-2(1-5), which activate both FPR1 and FPR2.

\subsection{Effects of Substituting Ala for Each Amino Acid Residue of MCT-2(1-15) on $\beta$-Hexosaminidase Release by Differentiated HL-60 Cells}

We examined the effect of substituting Ala for each amino acid residue in MCT-2(1-15) on the stimulation of $\beta$-hexosaminidase release to elucidate the contribution of each side chain structure to this process. As the MCT-2(1-7) structure with an N-formyl group was indicated as crucial for the activation of FPR2 (Figures 1-3), we investigated the effect of substituting Ala for each amino acid residue in positions one to seven within MCT-2(1-15). The replacement of Met $^{1}$ of MCT-2(1-15) with Ala caused a 30\% reduction of the maximum response with a dramatic ( $>500$-fold) increase in the $\mathrm{EC}_{50}$ value compared with MCT2(1-15) (Figure 4A and Table 2), indicating that the $\operatorname{Met}^{1}$ side chain is important for not only the affinity of MCT-2(1-15) to FPR2, but also for FPR2 activation. The substitution of $\mathrm{Met}^{4}, \mathrm{Arg}^{5}$, $\mathrm{Lys}^{6}$, or Ile ${ }^{7}$ with Ala also caused an increase in the $\mathrm{EC}_{50}$ value with the same level of maximum response as MCT-2(1-15). In contrast, the replacement of $\mathrm{Thr}^{2}$ with Ala promoted a remarkable decrease in the $\mathrm{EC}_{50}$ value without affecting the maximum response, although the substitution of $\mathrm{Pro}^{3}$ with Ala had no effect on the $\mathrm{EC}_{50}$ value. These results suggest that the side chains of $\mathrm{Met}^{4}, \mathrm{Arg}^{5}, \mathrm{Lys}^{6}$, and $\mathrm{Ile}^{7}$, and $\mathrm{Thr}^{2}$ within MCT-2(1-15) contribute positively and negatively, respectively, to its affinity to bind to FPR2. 

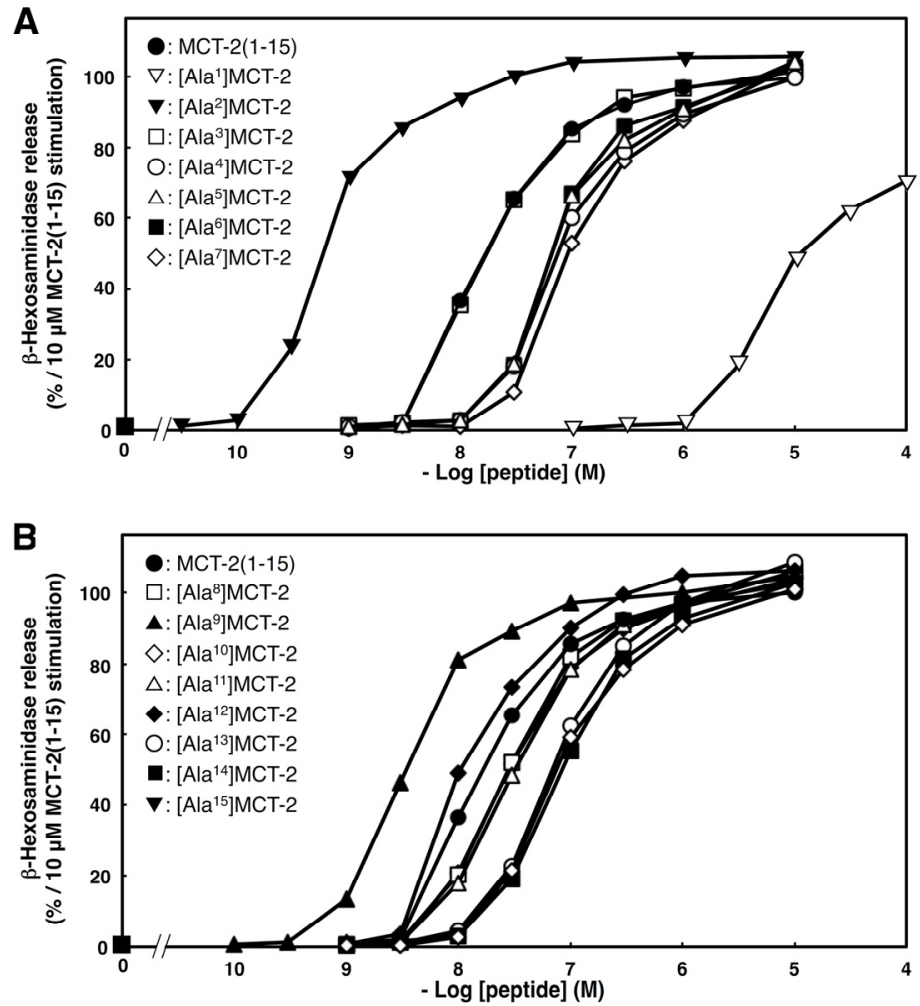

Figure 4. Effects of substituting Ala for each amino acid residue in the MCT-2(1-7) (A) or the MCT-2 (8-15) (B) sequence within MCT-2(1-15) on $\beta$-hexosaminidase release by differentiated HL-60 cells. The differentiated HL-60 cells were stimulated by MCT-2(1-15) or its derivatives at $37^{\circ} \mathrm{C}$ for $10 \mathrm{~min}$, and the amount of the released $\beta$-hexosaminidase was quantified as described in "Materials and Methods". The ability of each peptide to cause $\beta$-hexosaminidase release is expressed as a percentage of enzyme secretion promoted by $10 \mu \mathrm{M}$ MCT-2(1-15). Data are expressed as the mean $\pm \mathrm{SE}$ of four to six independent experiments.

Table 2. Amino acid sequences of MCT-2(1-15) and its Ala-substituted derivatives and their $\mathrm{EC}_{50}$ values and maximum effects on the induction of $\beta$-hexosaminidase release from differentiated HL-60 cells.

\begin{tabular}{|c|c|c|c|c|c|c|c|c|c|c|c|c|c|c|c|c|c|}
\hline \multirow[t]{2}{*}{ Peptide } & \multicolumn{15}{|c|}{ Sequence } & \multirow[t]{2}{*}{$\mathrm{EC}_{50}(\mathrm{nM})$} & \multirow[t]{2}{*}{ Maximum Effect $(\%)^{a}$} \\
\hline & & 1 & 2 & 3 & 4 & 5 & 6 & 7 & 8 & 9 & 10 & 11 & 12 & 1314 & 15 & & \\
\hline MCT-2(1-15) & formyl - & M & $\mathrm{T}$ & $\mathrm{P}$ & M & $\mathrm{R}$ & K & I & $\mathrm{N}$ & $\mathrm{P}$ & $\mathrm{L}$ & M & K & $\mathrm{L} \quad \mathrm{I}$ & $\mathrm{N}$ & $20.0 \pm 3.39$ & 100 \\
\hline$\left[\mathrm{Ala}^{1}\right] \mathrm{MCT}-2$ & formyl - & A & $\mathrm{T}$ & $\mathrm{P}$ & M & $\mathrm{R}$ & K & I & $\mathrm{N}$ & $\mathrm{P}$ & $\mathrm{L}$ & M & K & L I & $\mathrm{N}$ & $>10,000$ & $70 \pm 2 * * *$ \\
\hline$\left[\mathrm{Ala}^{2}\right] \mathrm{MCT}-2$ & formyl - & M & A & $\mathrm{P}$ & M & $\mathrm{R}$ & $\mathrm{K}$ & $\mathrm{I}$ & $\mathrm{N}$ & $\mathrm{P}$ & $\mathrm{L}$ & $\mathrm{M}$ & K & L I & $\mathrm{N}$ & $0.61 \pm 0.07$ & $106 \pm 2$ \\
\hline$\left[\mathrm{Ala}^{3}\right] \mathrm{MCT}-2$ & formyl - & M & $\mathrm{T}$ & A & M & $\mathrm{R}$ & $\mathrm{K}$ & I & $\mathrm{N}$ & $\mathrm{P}$ & $\mathrm{L}$ & $\mathrm{M}$ & K & L I & $\mathrm{N}$ & $16.3 \pm 0.29$ & $102 \pm 1$ \\
\hline$\left[\mathrm{Ala}^{4}\right] \mathrm{MCT}-2$ & formyl - & M & $\mathrm{T}$ & $\mathrm{P}$ & A & $\mathrm{R}$ & K & I & $\mathrm{N}$ & $\mathrm{P}$ & $\mathrm{L}$ & $\mathrm{M}$ & K & L I & $\mathrm{N}$ & $68.0 \pm 2.65$ & $100 \pm 2$ \\
\hline$\left[\mathrm{Ala}^{5}\right] \mathrm{MCT}-2$ & formyl - & M & $\mathrm{T}$ & $\mathrm{P}$ & M & A & K & I & $\mathrm{N}$ & $\mathrm{P}$ & $\mathrm{L}$ & $\mathrm{M}$ & K & L I & $\mathrm{N}$ & $61.3 \pm 0.58$ & $104 \pm 1$ \\
\hline$\left[\mathrm{Ala}^{6}\right] \mathrm{MCT}-2$ & formyl - & M & $\mathrm{T}$ & $\mathrm{P}$ & M & $\mathrm{R}$ & $\mathrm{A}$ & I & $\mathrm{N}$ & $\mathrm{P}$ & $\mathrm{L}$ & $\mathrm{M}$ & K & L I & $\mathrm{N}$ & $64.0 \pm 3.00$ & $103 \pm 2$ \\
\hline$\left[\mathrm{Ala}^{7}\right] \mathrm{MCT}-2$ & formyl - & M & $\mathrm{T}$ & $\mathrm{P}$ & M & $\mathrm{R}$ & $\mathrm{K}$ & A & $\mathrm{N}$ & $\mathrm{P}$ & $\mathrm{L}$ & M & K & $\mathrm{L}$ & $\mathrm{N}$ & $94.7 \pm 3.21$ & $104 \pm 2$ \\
\hline$\left[\mathrm{Ala}^{8}\right] \mathrm{MCT}-2$ & formyl - & M & $\mathrm{T}$ & $\mathrm{P}$ & M & $\mathrm{R}$ & K & I & $\mathrm{A}$ & $\mathrm{P}$ & $\mathrm{L}$ & M & K & $\mathrm{L}$ & $\mathrm{N}$ & $31.0 \pm 3.97$ & $106 \pm 1$ \\
\hline [Ala $\left.{ }^{9}\right] \mathrm{MCT}-2$ & formyl - & M & $\mathrm{T}$ & $\mathrm{P}$ & M & $\mathrm{R}$ & K & I & $\mathrm{N}$ & A & $\mathrm{L}$ & M & K & $\mathrm{L}$ & $\mathrm{N}$ & $3.02 \pm 1.21$ & $105 \pm 1$ \\
\hline$\left[\mathrm{Ala}^{10}\right] \mathrm{MCT}-2$ & formyl - & M & $\mathrm{T}$ & $\mathrm{P}$ & M & $\mathrm{R}$ & K & I & $\mathrm{N}$ & $\mathrm{P}$ & A & $\mathrm{M}$ & K & $\mathrm{L}$ & $\mathrm{N}$ & $73.0 \pm 13.3$ & $100 \pm 2$ \\
\hline$\left[\mathrm{Ala}^{11}\right] \mathrm{MCT}-2$ & formyl - & M & $\mathrm{T}$ & $\mathrm{P}$ & M & $\mathrm{R}$ & K & I & $\mathrm{N}$ & $\mathrm{P}$ & $\mathrm{L}$ & $\mathrm{A}$ & K & $\mathrm{L}$ & $\mathrm{N}$ & $36.7 \pm 11.0$ & $102 \pm 1$ \\
\hline$\left[\mathrm{Ala}^{12}\right] \mathrm{MCT}-2$ & formyl - & M & $\mathrm{T}$ & $\mathrm{P}$ & M & $\mathrm{R}$ & K & I & $\mathrm{N}$ & $\mathrm{P}$ & $\mathrm{L}$ & M & A & L I & $\mathrm{N}$ & $12.3 \pm 0.29$ & $106 \pm 3$ \\
\hline$\left[\mathrm{Ala}^{13}\right] \mathrm{MCT}-2$ & formyl - & M & $\mathrm{T}$ & $\mathrm{P}$ & M & $\mathrm{R}$ & K & I & $\mathrm{N}$ & $\mathrm{P}$ & $\mathrm{L}$ & $\mathrm{M}$ & K & A I & $\mathrm{N}$ & $83.7 \pm 3.54$ & $107 \pm 3$ \\
\hline$\left[\mathrm{Ala}^{14}\right] \mathrm{MCT}-2$ & formyl - & M & $\mathrm{T}$ & $\mathrm{P}$ & M & $\mathrm{R}$ & K & I & $\mathrm{N}$ & $\mathrm{P}$ & $\mathrm{L}$ & $\mathrm{M}$ & K & L A & $\mathrm{N}$ & $76.7 \pm 11.9$ & $103 \pm 3$ \\
\hline$\left[\right.$ Ala $\left.^{15}\right] \mathrm{MCT}-2$ & formyl - & M & $\mathrm{T}$ & $\mathrm{P}$ & M & $\mathrm{R}$ & $\mathrm{K}$ & $\mathrm{I}$ & $\mathrm{N}$ & $\mathrm{P}$ & $\mathrm{L}$ & $\mathrm{M}$ & K & $\mathrm{L} \quad \mathrm{I}$ & A & $29.3 \pm 1.49$ & $104 \pm 3$ \\
\hline
\end{tabular}

${ }^{a}$ The ability of each peptide to cause $\beta$-hexosaminidase release is expressed as a percentage of enzyme secretion promoted by $10 \mu \mathrm{M}$ MCT-2. Data are expressed as the mean $\pm \mathrm{SE}$ of four to six independent experiments. ${ }^{* * *} p<0.001$, values significantly different from MCT-2(1-15). 
We also examined the effect of substituting Ala for each amino acid residue in the MCT-2(8-15) sequence within MCT-2(1-15) because this structure may be important for the binding affinity between MCT-2(1-15) and FPR2, but not the receptor activation described above. The substitution of $\mathrm{Leu}^{10}$, $\mathrm{Leu}^{13}$, or Ile ${ }^{14}$ with Ala caused an increase in the $\mathrm{EC}_{50}$ value with the same level of maximum response as MCT-2(1-15) (Figure 4B and Table 2). In contrast, the replacement of Pro ${ }^{9}$ with Ala promoted a remarkable decrease in the $\mathrm{EC}_{50}$ value without affecting the maximum response $\left[\mathrm{EC}_{50}: 3 \pm 2 \mathrm{nM}\right.$, Figure $4 \mathrm{~B}$ and Table 2], although the substitution of $\mathrm{Asn}^{8}, \mathrm{Met}^{11}$, $\mathrm{Lys}^{12}$, or Asn ${ }^{15}$ with Ala had no effect. These results suggest that the $\mathrm{Leu}^{10}$, $\mathrm{Leu}^{13}$, or $\mathrm{Ile}^{14}$, and Pro ${ }^{9}$ side chains within MCT-2(1-15) contribute positively and negatively, respectively, to its affinity to bind to FPR2.

\subsection{Circular Dichroic Spectra of MCT-2(1-15) and Its Derivatives}

It was suggested that the $\mathrm{Thr}^{2}, \mathrm{Met}^{4}, \mathrm{Arg}^{5}, \mathrm{Lys}^{6}, \mathrm{Ile}^{7}, \mathrm{Pro}^{9}, \mathrm{Leu}^{10}, \mathrm{Leu}^{13}$, and $\mathrm{Ile}^{14}$ side chains within MCT-2(1-15) had an effect on its binding affinity to FPR2 and that the MCT-2(8-15) structure was important for binding to FPR2. Thus, the secondary structures of MCT-2(1-15) and its derivatives were analyzed using circular dichroic (CD) spectra, which is an excellent tool for the rapid investigation of secondary structures. As we reported previously [45], the CD spectrum of MCT-2(1-15) exhibited two minima at $225 \mathrm{~nm}$ and $205 \mathrm{~nm}$ in TFE solution, suggesting that MCT-2(1-15) predominantly contained an $\alpha$-helical structure in hydrophilic circumstance (Figure 5A). Similarly, the spectra of the $\mathrm{N}$-terminal MCT-2 derivatives that were truncated by one to six amino acid residues from the C-terminus of MCT-2(1-15) at $100 \mu \mathrm{M}$ also showed two minima at $225 \mathrm{~nm}$ and 202-208 nm in TFE solution, although these minima were consecutively attenuated by the C-terminal truncations (Figure 5B-G). Moreover, the spectra of MCT-2(1-8) and MCT-2(1-7) displayed a minimum at approximately $200 \mathrm{~nm}$ in TFE solution (Figure $5 \mathrm{H}, \mathrm{I}$ ), proposing that MCT-2(1-8) and MCT-2(1-7) do not contain defined secondary structures, even under hydrophilic conditions. In contrast, the $\mathrm{CD}$ spectra of all of these derivatives including MCT-2(1-15) at $100 \mu \mathrm{M}$ exhibited a minimum at approximately $200 \mathrm{~nm}$ in a hydrophilic phosphate buffer (Figure 5), proposing that MCT-2(1-15) and its derivatives did not form defined secondary structures in hydrophilic conditions.

\subsection{Time-Dependent Alterations of the Molecular Forms of MCT-2(1-15) in Serum}

We examined the alterations of the molecular forms of MCT-2(1-15) in serum to elucidate the time-dependent degradation of MCT-2(1-15). MCT-2(1-15) was incubated with mouse serum, and the production of MCT-2-derived peptides was analyzed by reverse phase (RP)-HPLC. The molecular masses of the newly produced peaks were measured by MALDI-TOF-mass spectrometry (MS) to identify the molecular forms of the MCT-2-related peptides. As a result, the amount of MCT-2(1-15) in serum was reduced by approximately $50 \%$ and $80 \%$ at 1 and $2 \mathrm{~h}$ after incubation, respectively, and MCT-2(1-15) completely disappeared at $4 \mathrm{~h}$ (Figure 6), indicating that its half-life in serum was approximately $1 \mathrm{~h}$. In contrast, MCT-2(1-11), MCT-2(1-10), and MCT-2(1-4) were produced simultaneously with the decrease in the amount of MCT-2(1-15), that is, the production of MCT-2(1-11) and MCT-2(1-10) was detected at $1 \mathrm{~h}$, and the maximum amounts of MCT-2(1-11) and MCT-2(1-10) were observed at 1 and $2 \mathrm{~h}$ after incubation, respectively (Figure 6B,C). MCT2(1-11) and MCT-2(1-10) were not found at $4 \mathrm{~h}$ after incubation (Figure 6D). MCT-2(1-4) was detected initially at $1 \mathrm{~h}$ after incubation but at a low level, and its maximum level was observed at $4 \mathrm{~h}$ (Figure 6B-F). The amount of MCT-2(1-4) was then reduced gradually over time, but it was still present at $48 \mathrm{~h}$ (Figure 6F). In addition, no fragmented peptides derived from MCT-2(1-15) were observed at any time points. These results suggest that MCT-2(1-15) is degraded by various proteases in serum, and MCT-2(1-11), MCT-2(1-10), and MCT-2(1-4) are produced simultaneously. Moreover, it is considered that MCT-2(1-4) may be produced by the degradation of MCT-2(1-15), MCT-2(1-11), or MCT-2(1-10), and was present in serum for more than $48 \mathrm{~h}$. These findings suggest that MCT-2(1-15) exerts its functions not only as MCT-2(1-15) but also as MCT-2(1-11), MCT-2(1-10), and MCT-2(1-4). 
A

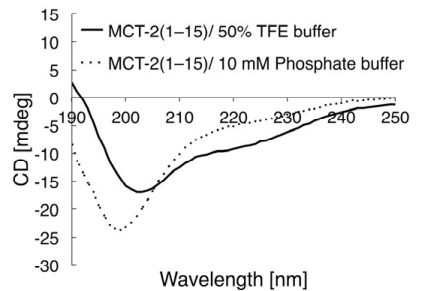

D
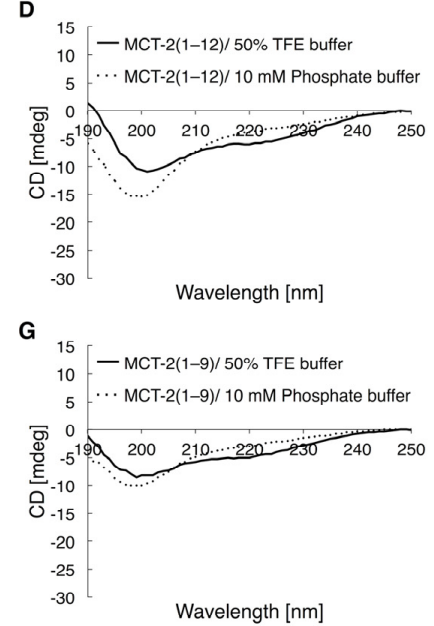

B

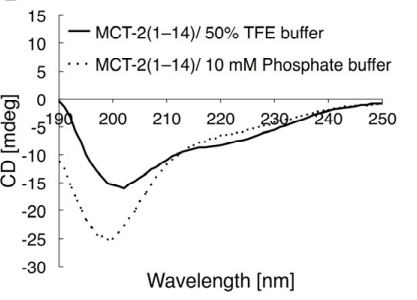

E
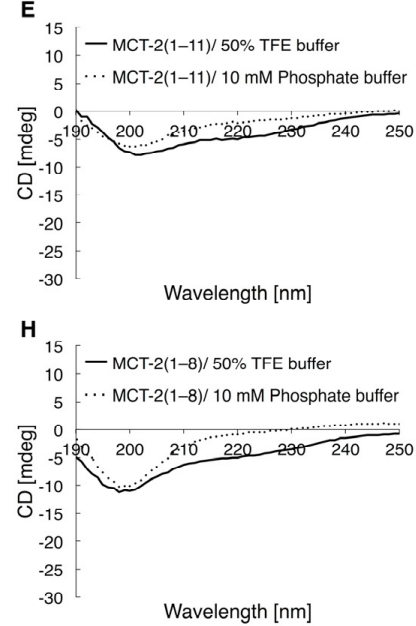

C

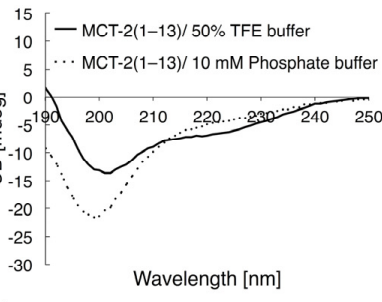

$\mathbf{F}_{15}$

${ }_{10}^{15} \mid-$ MCT-2(1-10)/ 50\% TFE buffer

5 -... MCT-2(1-10)/ $10 \mathrm{mM}$ Phosphate buffer

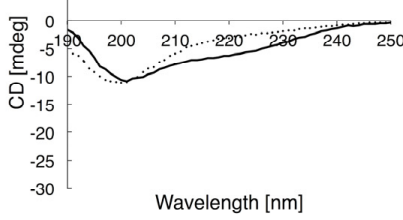

1 ,

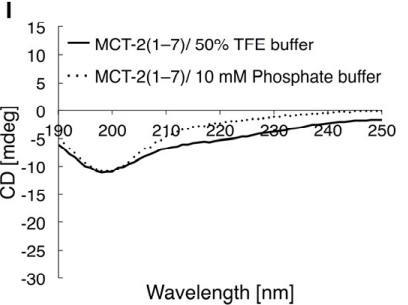

Figure 5. CD spectra of MCT-2(1-15) and its derivatives. The CD spectra of MCT-2(1-15) (A), MCT-2(1-14) (B), MCT-2(1-13) (C), MCT-2(1-12) (D), MCT-2(1-11) (E), MCT-2(1-10) (F), MCT-2(1-9) (G), MCT-2(1-8) (H), and MCT-2(1-7) (I) in 50\% TFE buffer (solid lines) or $10 \mathrm{mM}$ phosphate buffer ( $\mathrm{pH}$ 7.4) (dashed lines) were measured with a CD spectrometer. CD data with peptide solutions (final concentration: $100 \mu \mathrm{M}$ ) were the average of five scans collected at $1 \mathrm{~nm}$ intervals. The results are expressed as optical rotation (mdeg).
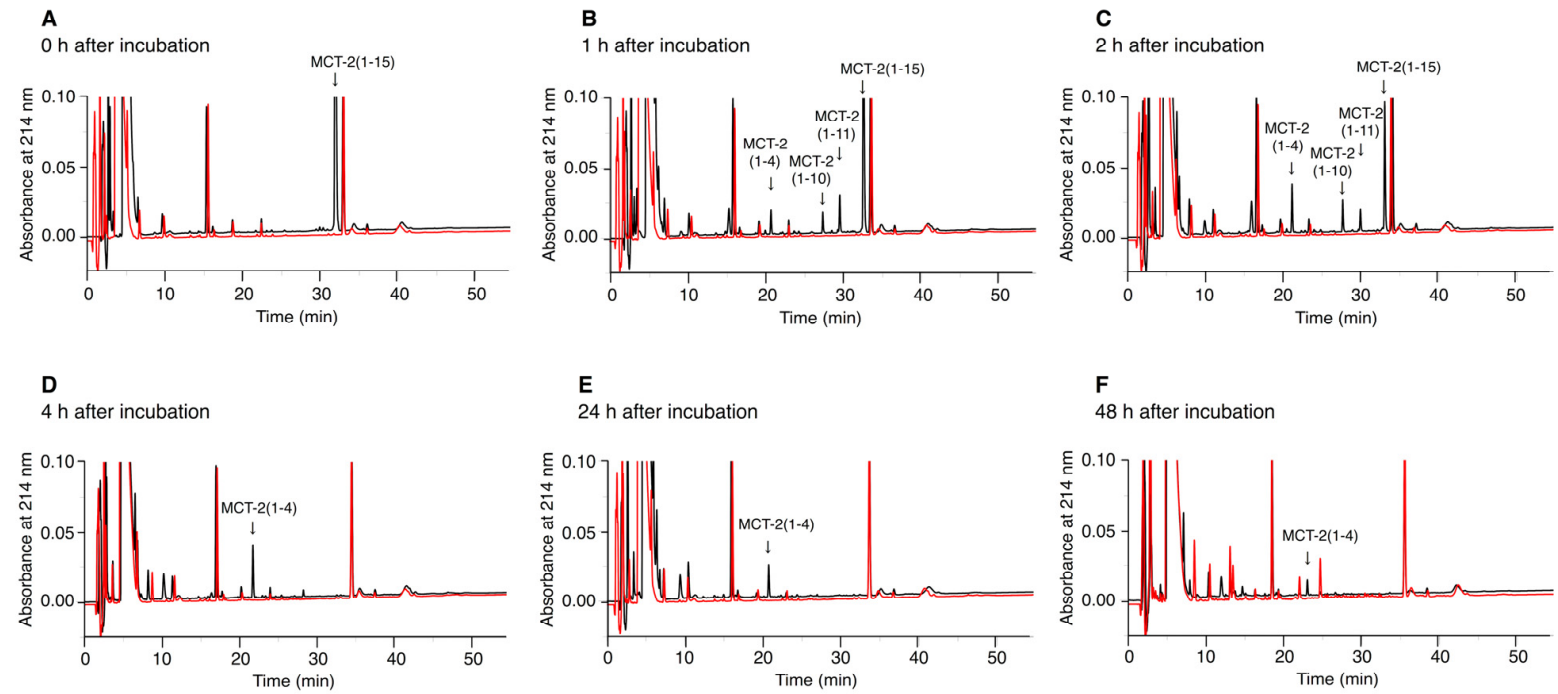

E

$24 \mathrm{~h}$ after incubation

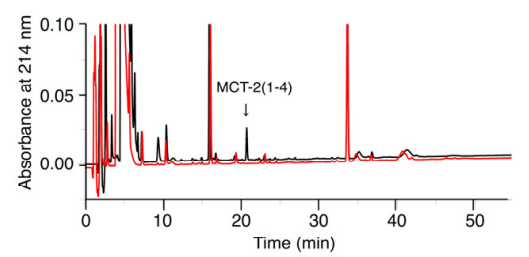

$\mathbf{F}$

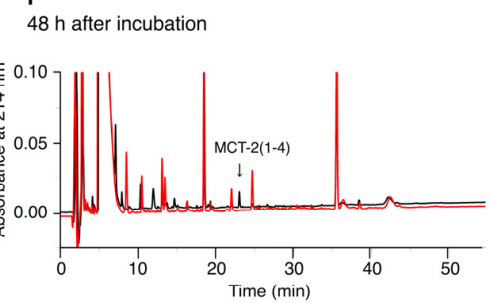

Figure 6. Time-dependent alteration of the molecular forms of MCT-2(1-15) in serum. The alteration of the molecular forms of MCT-2(1-15) in serum was examined as described in the Materials and Methods. Briefly, MCT-2(1-15) was incubated in mouse serum at $37^{\circ} \mathrm{C}$ for $0,1,2,4,24$, and $48 \mathrm{~h}$, and samples at those time points were analyzed by RP-HPLC. The panels show the analytical RP-HPLC profile of each sample at 0 (A), 1 (B), 2 (C), 4 (D), 24 (E), or 48 (F) h after incubation. Black and red lines indicate the samples that were incubated with and without MCT-2(1-15), respectively. Analytical conditions: column, $5 \mathrm{C}_{18}$ column $(4.6 \times 150 \mathrm{~mm})$; elution with a linear gradient from $10 \%$ to $60 \% \mathrm{CH}_{3} \mathrm{CN} / 0.1 \%$ trifluoroacetic acid for $50 \mathrm{~min}$; flow rate, $1 \mathrm{~mL} / \mathrm{min}$; detection wavelength, $214 \mathrm{~nm}$. The arrows indicate the peaks containing MCT-2(1-15) or its related peptides that were identified by MALDI-TOF-MS. 


\section{Discussion}

\subsection{Recognition Mechanisms of MCT-2(1-15) and Its Derivatives by Formyl-Peptide Receptors}

FPR1, which recognizes N-formylated peptides, and its homolog FPR2 are expressed in neutrophils and neutrophilic differentiated HL-60 cells [33-35,38,48-51], and the endogenous pentadecapeptide MCT-2(1-15) specifically activates FPR2 but not FPR1 [36,45] (see also Figures 1-3). At first, we examined the structure-activity relationships of MCT-2(1-15) to identify the minimum structure that is required for specific FPR2 activation. We found that the N-formyl group of MCT-2(1-15) was crucial for the induction of $\beta$-hexosaminidase release stimulated by the peptide, and suggested that the $\operatorname{Met}^{1}$ side chain contributed not only to the affinity of MCT-2(1-15) to bind to FPR2 but also to receptor activation (Figures 1-4).

We also showed that MCT-2(1-4), which is an N-terminal tetrapeptide of MCT-2(1-15), induced $\beta$-hexosaminidase release, but surprisingly, MCT-2(1-4) specifically activated FPR1 (Figures 1-3). Specifically, the evidence that MCT-2(1-4) promoted an increase of $\left[\mathrm{Ca}^{2+}\right]_{\mathrm{i}}$ in HEK-293 cells expressing FPR1 but not in those expressing FPR2, as well as the evidence that its stimulation for $\beta$-hexosaminidase secretion was specifically inhibited by the FPR1 inhibitor CysH but not FPR2 inhibitor PBP10 indicates that MCT-2(1-4) induces $\beta$ hexosaminidase secretion in differentiated HL-60 cells via the specific activation of FPR1. In addition, MCT-2(1-5), a derivative that was extended by C-terminal one amino acid residue to MCT-2(1-4), also exhibited the induction of $\beta$-hexosaminidase release (Figure 2C), but in contrast with MCT-2(1-4), MCT-2(1-5) caused an increase of $\left[\mathrm{Ca}^{2+}\right]_{\mathrm{i}}$ in both FPR1- and FPR2-expressing HEK-293 cells (Figure 1F,G). These findings suggest that MCT-2(1-5) promotes $\beta$-hexosaminidase secretion via the activation of FPR1 and FPR2. The idea that MCT-2(1-5) activates FPR1 and FPR2 to induce $\beta$-hexosaminidase secretion was also supported by the use of selective inhibitors against FPR1 and FPR2; the stimulation of MCT-2(1-5) was partially inhibited by CysH or PBP10 and was completely prevented by a combination of both inhibitors (Figure 3C).

In contrast with MCT-2(1-4) and MCT-2(1-5), MCT-2(1-7) induced $\beta$-hexosaminidase release via the specific activation of FPR2. Indeed, MCT-2(1-7) promoted $\beta$-hexosaminidase secretion in differentiated HL-60 cells and caused an increase of $\left[\mathrm{Ca}^{2+}\right]_{i}$ in HEK-293 cells expressing FPR2 but not in those expressing FPR1 (Figures 1E and 2B). MCT-2(1-7) was also demonstrated to be a full agonist for FPR2 because the maximum response of MCT$2(1-7)$ to potentiate $\beta$-hexosaminidase secretion was at the same level as that induced by MCT-2(1-15), an endogenous specific agonist for FPR2. Moreover, $\mathrm{N}$-terminal derivatives longer than MCT-2(1-7) also exhibited the same maximum effect as MCT-2(1-15) on the stimulation of $\beta$-hexosaminidase release, and those $\mathrm{EC}_{50}$ values were simultaneously reduced by $\mathrm{C}$-terminal extension, that is, the activity of the derivatives was consecutively potentiated (Figure 2B). In addition, similar to MCT-2(1-7), the N-terminal derivatives MCT-2(1-8), MCT-2(1-9), and MCT-2(1-10) as well as MCT-2(1-15) caused an increase of $\left[\mathrm{Ca}^{2+}\right]_{\mathrm{i}}$ only in HEK-293 cells expressing FPR2 (Figure 1A-E). These findings indicate that the N-terminal derivatives longer than MCT-2(1-7) are also specific full agonists for FPR2 to promote $\beta$-hexosaminidase secretion. This notion concerning the receptor preference of MCT-2(1-15) and its derivatives was also supported by experiments using selective inhibitors against FPR1 and FPR2. Specifically, the stimulation of $\beta$-hexosaminidase release by MCT-2(1-7) and its longer N-terminal derivatives was completely inhibited by the FPR2 inhibitor PBP10, but was unaffected by the FPR1 inhibitor CysH (Figure 3A,B).

MCT-2(1-6) did not induce an increase of $\left[\mathrm{Ca}^{2+}\right]_{\mathrm{i}}$ in HEK-293 cells expressing either FPR2 or FPR1, even at $100 \mu \mathrm{M}$; nevertheless, it caused $\beta$-hexosaminidase secretion (Figure 2). The apparent discrepancy between the induction of $\beta$-hexosaminidase release and increase in $\left[\mathrm{Ca}^{2+}\right]_{\mathrm{i}}$ stimulated by MCT-2(1-6) may be a result of its weak stimulatory activity for not only FPR1, but also FPR2; the weak stimulation of $\beta$-hexosaminidase release by MCT-2(1-6) was presumably a consequence of the slight activation of both FPR1 and FPR2, although this was not evident in HEK-293 cells expressing FPR1 or FPR2. The idea that MCT-2(1-6) weakly activates FPR1 and FPR2 for the induction of $\beta$-hexosaminidase 
secretion was also supported by the use of selective inhibitors against FPR1 or FPR2, i.e., $\beta$-hexosaminidase release stimulated by MCT-2(1-6) was partially inhibited by either CysH or PBP10, and was completely prevented by a combination of both inhibitors (Figure $3 \mathrm{~A}-\mathrm{C}$ ).

\subsection{Secondary Structures of MCT-2(1-15) and Its Derivatives for the Interaction with FPR2}

In the present study, we showed that the MCT-2(1-7) structure within MCT-2(1-15) is required to induce the maximum response by FPR2 activation. What is the role of the C-terminal MCT-2(8-15) sequence within MCT-2(1-15)? Truncation of one to eight amino acid residues from the C-terminus of MCT-2(1-15) had no effect on the maximum response for the stimulation of $\beta$-hexosaminidase release, but did cause a consecutive increase of $\mathrm{EC}_{50}$ values (Figure 2B and Table 1), suggesting that the MCT-2(8-15) structure contributes to the binding affinity of MCT-2(1-15) to FPR2, but is not essential for the receptor activation itself. Especially, the removal of the $\mathrm{Ile}^{14}$, $\mathrm{Leu}^{13}, \mathrm{Met}^{11}$, and Leu ${ }^{10}$ side chains from MCT-2(1-15) significantly increased the $\mathrm{EC}_{50}$ values, suggesting that these hydrophobic amino acid residues are important for the affinity of MCT-2(1-15) with FPR2. Many bioactive peptides form amphipathic $\alpha$-helical structures when interacting with the cell membrane, and the hydrophobic side chains of those peptides influence their affinity for the cell membrane and their receptors [52,53]. Indeed, MCT-2(1-15) exhibited $\alpha$-helical signals in CD spectra in hydrophilic conditions, and the truncation of one to eight amino acid residues from its $C$-terminus caused a simultaneous decrease of the $\alpha$-helical signals (Figure 5). These findings propose that the $\alpha$-helical structure of MCT-2(1-15) formed in hydrophobic circumstance may also contribute to its interaction with FPR2. Here, the substitution of Pro ${ }^{9}$ in MCT-2(1-15) with Ala remarkably decreased the $\mathrm{EC}_{50}$ value for $\beta$-hexosaminidase release, i.e., its activity was potentiated by the exchange (Figure 4B). Taken together with our previous findings that the replacement of Pro ${ }^{9}$ in MCT-2(1-15) with Ala increased the $\alpha$-helical content in hydrophilic conditions [45], the importance of the amphiphilic $\alpha$-helical structure of the C-terminal part of MCT-2(1-15) for the improvement of its affinity for FPR2 was also supported by these results.

In this study, the $\mathrm{Thr}^{2}$ side chain was also suggested to contribute negatively to the affinity of MCT-2(1-15) for FPR2, that is, the replacement of $\mathrm{Thr}^{2}$ in MCT-2(1-15) with Ala promoted a remarkable decrease in the $\mathrm{EC}_{50}$ value (Table 2); nevertheless, this substitution did not influence the $\alpha$-helical content of MCT-2(1-15) [45]. Hence, the increase in activity by its replacement may be a result of an increase in hydrophobicity at position two that improves its binding affinity with FPR2.

\subsection{Binding Characteristics of MCT-2(1-15) and Its Derivatives to FPR1 and FPR2}

Recently, the tertiary structure of the FPR2- $\mathrm{G}_{\mathrm{i}}$ complex analyzed by cryo-electron microscopy (EM) has been reported, and that of the FPR1- $\mathrm{G}_{i}$ complex was also predicted based on the structure of FPR2 by Zhuang et al. [54]. In addition, formylated peptides containing fMLF were docked to those receptors. These findings suggested that the Nformyl groups of those peptides interacted with the Asp ${ }^{106}, \mathrm{Arg}^{201}$, and $\mathrm{Arg}^{205}$ residues distributed at the bottom of the ligand-binding cavities of FPR1 and FPR2 for the activation of both receptors. Thus, we simulated the docking of MCT-2(1-15) and its derivatives to FPR2 and FPR1 using the Glide program in Schrödinger, which was the program used by Zhuang et al. [54] (Figure 7, Marutani et al., manuscript in preparation). In brief, the Nformyl group of MCT-2(1-15) and its N-terminal derivatives longer than seven amino acid residues were also shown to interact with Asp ${ }^{106}$, Arg ${ }^{201}$, and Arg ${ }^{205}$ of FPR2 but not those of FPR1 because these peptides caused steric hindrance on binding to the cavity of FPR1 (Figure 7A and C vs. Figure 7E,G). Moreover, the $\mathrm{Met}^{1}$ side chains of those peptides filled the space at the bottom of the ligand-binding cavity of FPR2 (Figure 7A,C), presumably contributing to the stabilization of the interaction between the N-formyl groups of those peptides and $\mathrm{Asp}^{106}, \mathrm{Arg}^{201}$, and $\mathrm{Arg}^{205}$ of FPR2 for receptor activation. 
A
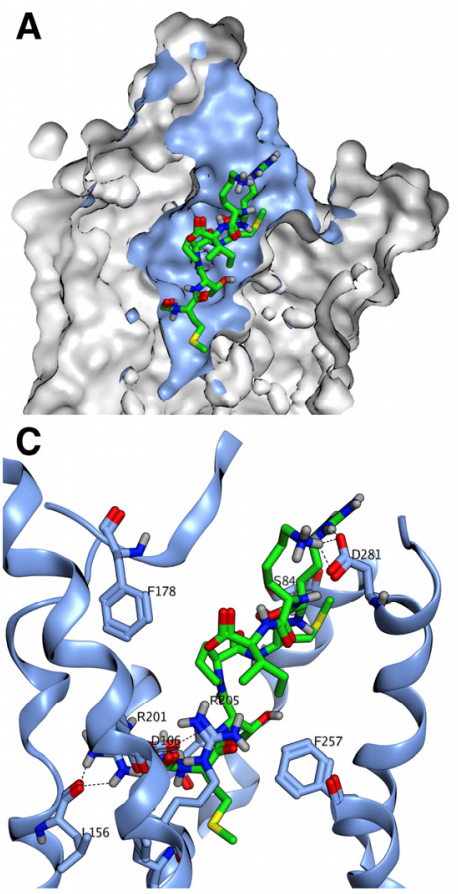

E

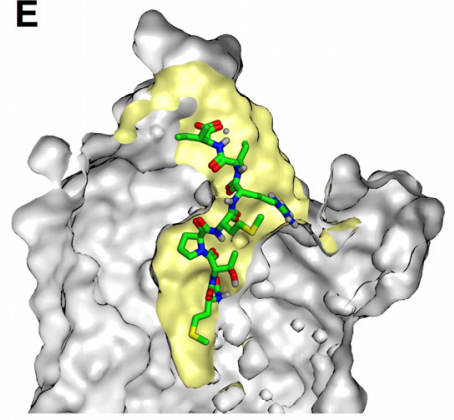

G

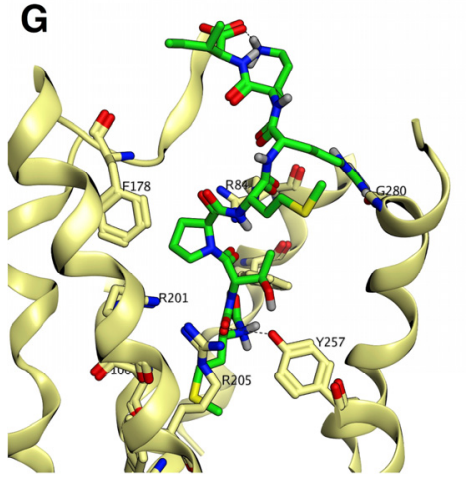

B
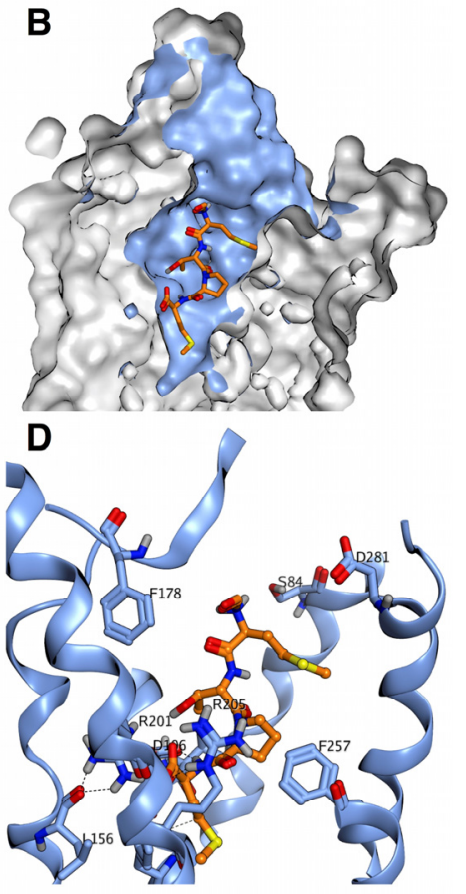

$\mathbf{F}$
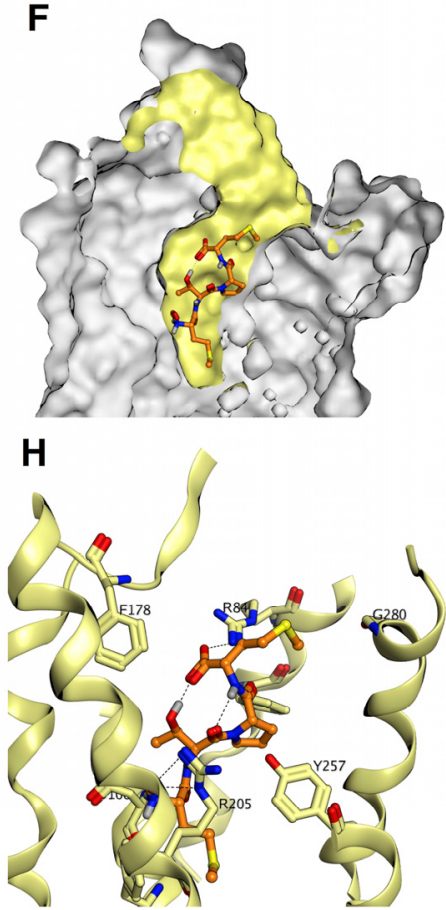

Figure 7. Molecular docking of MCT-2(1-7) and MCT-2(1-4) to FPR2 or FPR1. MCT-2(1-7) and MCT-2(1-4) are shown as green sticks and orange sticks, respectively. (A,B) The docking model of MCT-2(1-7) (A) and MCT-2(1-4) (B) to FPR2. (C,D) Detail of the ligand-binding cavity of FPR2. The structure of the ligand-binding cavity of FPR2 is shown in blue. (E,F) The docking model of MCT-2(1-7) (E) and MCT-2(1-4) (F) to FPR1. (G,H) Detail of the ligand-binding cavity of FPR1. The structure of the ligand-binding cavity of FPR1 is shown in yellow. Hydrogen bonding interactions are shown as dashed lines.

In contrast, MCT-2(1-4) just fit into the binding cavity of FPR1 to promote the interaction between its $\mathrm{N}$-formyl group and $\mathrm{Asp}^{106}, \mathrm{Arg}^{201}$, and $\mathrm{Arg}^{205}$ (Figure 7F,H). However, the interaction between MCT-2(1-4) and the ligand-binding cavity of FPR2 was not stabilized due to the lack of hydrophobic and hydrogen bonding interactions as well as the 
large binding cavity (Figure 7B,D) (docking score: FPR1-MCT-2(1-4) model, -4.84 vs. FPR2-MCT-2(1-4) model, -3.84).

In addition, the $\mathrm{Arg}^{5}$ or $\mathrm{Lys}^{6}$ residue of MCT-2(1-7) and the C-terminal carboxyl group of MCT-2(1-4) were exhibited to form hydrogen bonds with the Asp ${ }^{281}$ residue of FPR2 and the $\mathrm{Arg}^{84}$ residue of FPR1 (Figure 7C,H), respectively, which are distributed at the top of the binding cavities of those receptors, proposing that these hydrogen bonding interactions are of importance for stabilizing further receptor-peptide binding. The present simulation results can well explain those from structure-activity studies of the peptides in the present study in which MCT-2(1-7) and its derivatives longer than seven amino acid residues specifically activated FPR2, whereas MCT-2(1-4) specifically activated FPR1.

\subsection{Alteration of the Molecular Forms of MCT-2(1-15) in the Bloodstream}

Since the receptor preference of MCT-2(1-15) and its derivatives critically depends on the length of its C-terminus, changes in the molecular forms of MCT-2(1-15) in serum were investigated. MCT-2(1-15) in serum was detected within $4 \mathrm{~h}$ after incubation, and its half-life was approximately $1 \mathrm{~h}$ (Figure 6). In addition, the production of MCT-2-related FPR2 specific agonists MCT-2(1-11) and MCT-2(1-10) was observed at $1 \mathrm{~h}$ after incubation, but they were no longer present at $4 \mathrm{~h}$, similar to MCT-2(1-15) (Figure 6). Since MCT-2(1-15) is proposed to be released into the bloodstream from injury tissues as discussed below, these results suggest that MCT-2(1-15) released into the bloodstream initially activates FPR2 for several hours. In contrast, the MCT-2-related FPR1 specific agonist MCT-2(1-4) was found at low levels at $1 \mathrm{~h}$ after incubation; its levels then increased gradually over time, and its maximum amount was observed at $4 \mathrm{~h}$. Moreover, MCT-2(1-4) was still present at $48 \mathrm{~h}$ (Figure 6). These findings propose that MCT-2(1-15) released into the bloodstream is degraded and the resulting product, MCT-2(1-4), induces the activation of FPR1 following FPR2 activation and continues to activate FPR1 for over $48 \mathrm{~h}$.

\subsection{Possible Physiological Roles of the Receptor Preference Shift of MCT-2(1-15) from FPR2 to FPR1}

The results of this study demonstrate that the receptor preference of MCT-2(1-15) is shifted from FPR2 to FPR1 by the cleavage of its C-terminus. What is the physiological significance of this shift in receptor preference?

FPR1 and FPR2 play critical roles in inflammation including proinflammatory responses, subsequent resolution, and wound healing/tissue regeneration. Specifically, FPR1 and FPR2 are expressed mainly by inflammatory immune cells including neutrophils, monocytes, and monocyte-derived macrophage cells such as tissue-resident macrophages and microglia $[35,37,38]$, and FPR2 is also expressed by a variety of cells including microvascular endothelial cells [38,39]. FPR1 and FPR2 have roles in the mechanisms concerning the infiltration of neutrophils and macrophages into injury sites, and their activation causes various inflammatory responses, including phagocytosis, superoxide generation, and inflammatory cytokine production $[35,37,38]$. In addition, there is evidence indicating that the activation of FPR2 increases the vascular permeability of endothelial cells $[38,39]$, suggesting a further promotion of neutrophil infiltration from the bloodstream into injury sites following receptor activation in the initial stage of inflammation. Thus, the activation of FPR1 and FPR2 expressed by neutrophils, macrophages, and endothelial cells induces various innate immune responses initiated by the infiltration and activation of neutrophils. Oppositely, it is known that liganded FPR2 suppresses the production of inflammatory cytokines following the acute proinflammatory responses [38,55-58]. Moreover, FPR1 activation has been demonstrated to promote wound healing/tissue regeneration, including cell proliferation [40-44].

It is believed that mitochondrial-derived $\mathrm{N}$-formylated peptides activate FPR1 and FPR2 as endogenous activating factors. Indeed, mtDAMPs consisting of mitochondria and their contents are released into the bloodstream as a result of sterile tissue damage, such as trauma [15-21], and still unidentified endogenous $\mathrm{N}$-formylated peptides in mtDAMPs are thought to activate FPR1 and/or FPR2 to induce innate immune responses $[15,17,28]$. 
MCT-2(1-15) is the only endogenous $\mathrm{N}$-formylated peptide whose chemical structure has been determined so far, and the presence of MCT-2-related peptides in mtDAMPs was recently observed by immunoblot analysis using a monoclonal antibody against MCT-2 (Tsutsumi et al., unpublished observation). Taken together with these findings, the present results suggest the hypothesis that MCT-2(1-15) is initially released into the bloodstream from damaged cells following tissue injury, and then activates FPR2 specifically to induce acute innate immune responses, including the infiltration and activation of neutrophils (Figure 8). MCT-2(1-15) is then degraded in damaged tissues as well as in the bloodstream over time, and the resulting MCT-2-related FPR1 specific agonist MCT-2(1-4) activates FPR1 to promote delayed responses, which may include resolution and wound healing/tissue regeneration. Indeed, we recently found that a specific neutralizing monoclonal antibody against MCT-2 attenuated the infiltration of neutrophils into injured liver tissue in acetaminophen- or LPS-induced inflammation and prolonged the survival of mice, suggesting that MCT-2(1-15) and its derivatives play a critical role in innate immunity (Takamuro et al., manuscript in preparation). The present findings also indicate the crucial importance of investigating the molecular forms and/or exact chemical structures of those activating factors to elucidate the mechanisms underlying innate immune responses.

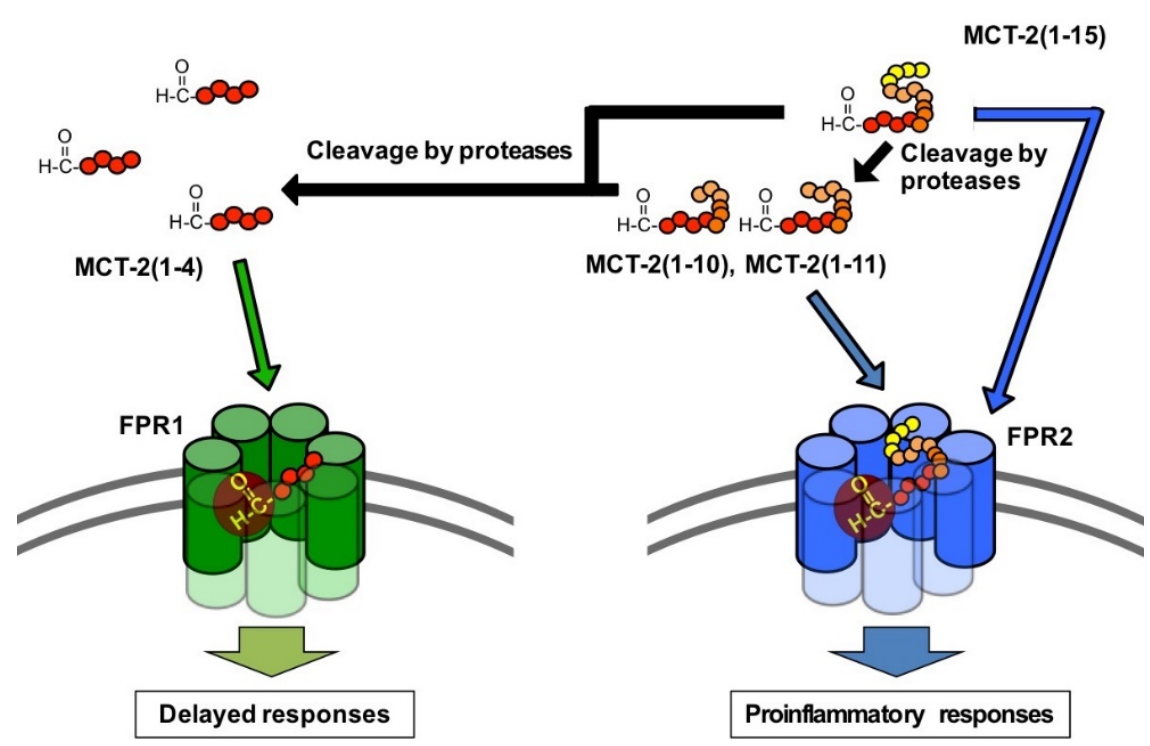

Figure 8. Proposed mechanisms of innate immune responses involving MCT-2(1-15). MCT-2(1-15) released from damaged cells firstly activates FPR2 to induce proinflammatory responses. Released MCT-2(1-15) is then degraded over time to produce MCT-2(1-4), and the resultant MCT-2(1-4) activates FPR1 to promote delayed responses, which may be related to resolution and wound healing/tissue regeneration. See the "Discussion" in detail.

\section{Materials and Methods}

\subsection{Peptides}

Human MCT-2 and its derivatives (Tables 1 and 2) were chemically synthesized by a solid-phase method [59-62] using a 9-fluorenylmethyloxycarbonyl strategy [12,36]. Synthetic peptides were purified by RP-HPLC on a $C_{18}$ column $(20 \times 250 \mathrm{~mm}$, COSMOSIL; Nacalai Tesque, Inc., Kyoto, Japan). These peptides were analyzed by RP-HPLC on a $C_{18}$ column (4.6 $\times 150 \mathrm{~mm}$, COSMOSIL; Nacalai Tesque, Inc.) and were proven to be more than $95 \%$ pure (Figures $\mathrm{S} 1$ and S2). The molecular weights of the synthesized peptides were also confirmed by MALDI-TOF-MS (Table S1). fMLF was purchased from Nacalai Tesque, Inc.

\subsection{Preparation of Cells}

HEK-293 cells (American Type Culture Collection, Manassas, VA, USA) were maintained in DMEM (Thermo Fisher Scientific, Waltham, MA, USA) containing 10\% FBS 
(Thermo Fisher Scientific) in a humidified atmosphere at $5 \% \mathrm{CO}_{2}$ and $37{ }^{\circ} \mathrm{C}$. Human acute leukemia-derived HL-60 cells (RIKEN Cell Bank, Ibaraki, Japan) were cultured in RPMI1640 medium (Thermo Fisher Scientific) containing 10\% FBS in a humidified atmosphere at $5 \% \mathrm{CO}_{2}$ and $37^{\circ} \mathrm{C}$. HL-60 cells were treated with $500 \mu \mathrm{M}$ dibutyryl-cAMP (Sigma-Aldrich, St. Louis, MO, USA) for $72 \mathrm{~h}$ to differentiate the cells into neutrophilic/granulocytic cells as described elsewhere [50].

\subsection{Establishment of HEK-293 Cells Stably Expressing FPR1 or FPR2}

HEK-293 cells stably expressing FPR1 or FPR2 with a G $\alpha_{16}$ type of G protein were established, as described previously [36]. Briefly, HEK-293 cells were transfected with human FPR1/pcDNA3.1/Zeo or human FPR2/pcDNA3.1/Zeo using Lipofectamine 2000 (Thermo Fisher Scientific). The cells were also co-transfected with $\mathrm{G} \alpha_{16} / \mathrm{pcDNA3.1/Hygro}$ to induce an agonist-promoted increase in $\left[\mathrm{Ca}^{2+}\right]_{i}$. One cell was placed into each well of a 96-well plate and selected with $100 \mu \mathrm{g} / \mathrm{mL}$ hygromycin (FUJIFILM Wako Pure Chemical, Osaka, Japan) and $250 \mu \mathrm{g} / \mathrm{mL}$ Zeocin (InvivoGen, San Diego, CA, USA). Individual cells were further selected by measuring increases in $\left[\mathrm{Ca}^{2+}\right]_{i}$ stimulated by $1 \mu \mathrm{M}$ fMLF.

\subsection{Measurement of $\left[\mathrm{Ca}^{2+}\right]_{i}$}

The increase in $\left[\mathrm{Ca}^{2+}\right]_{i}$ stimulated by peptides was assessed, as described previously [11,36]. In brief, HEK-293 cells stably expressing FPR1 or FPR2 with a G $\alpha_{16}$ type of G protein were washed twice with a HEPES-Na solution ( $5 \mathrm{mM} \mathrm{HEPES,} 140 \mathrm{mM} \mathrm{NaCl}, 4 \mathrm{mM}$ $\mathrm{KCl}, 1 \mathrm{mM} \mathrm{NaH}_{2} \mathrm{PO}_{4}, 1 \mathrm{mM} \mathrm{MgCl}, 1.25 \mathrm{mM} \mathrm{CaCl}_{2}, 11 \mathrm{mM}$ glucose, and 0.2\% BSA, pH 7.4). The $\mathrm{Ca}^{2+}$-sensitive fluorescence reagent Fura-2-acetoxymethyl ester (Dojin, Kumamoto, Japan) was added to the cell suspension ( $4 \mathrm{~mL}$; final concentration: $4 \mu \mathrm{M})$. The reaction mixture was shielded from light and shaken gently at $37^{\circ} \mathrm{C}$ for $60 \mathrm{~min}$ to load the cells with Fura-2. The cells were subsequently washed twice with the HEPES-Na solution and a cell suspension was diluted to a final density of $5.0 \times 10^{5}$ cells $/ \mathrm{mL}$. The cell suspension $(1 \mathrm{~mL})$ was placed into a cuvette and stimulated by peptide solutions $(5 \mu \mathrm{L})$ with stirring at $37^{\circ} \mathrm{C}$. The ratio of fluorescence intensity at $500 \mathrm{~nm}$ by excitation wavelengths of $340 \mathrm{~nm}$ and 380 nm was measured using a fluorometer (CAF-100; Japan Spectroscopic Co., Tokyo, Japan).

\subsection{Assay of $\beta$-Hexosaminidase Release}

The ability of MCT-2-related peptides to activate HL-60 cells differentiated into neutrophilic/granulocytic cells was evaluated by stimulation of $\beta$-hexosaminidase secretion from the cells [63]. Briefly, differentiated HL-60 cells were washed 3 times with ice-cold HEPES-buffered Hank's solution (HBHS; 10 mM HEPES, $136.9 \mathrm{mM} \mathrm{NaCl}, 5.4 \mathrm{mM} \mathrm{KCl}$, $1.2 \mathrm{mM} \mathrm{CaCl}_{2}, 0.44 \mathrm{mM} \mathrm{KH}_{2} \mathrm{PO}_{4}, 0.49 \mathrm{mM} \mathrm{MgCl}_{2}, 0.41 \mathrm{mM} \mathrm{MgSO}_{4}, 0.34 \mathrm{mM} \mathrm{Na}_{2} \mathrm{HPO}_{4}$, $5.5 \mathrm{mM}$ glucose, $4.2 \mathrm{mM} \mathrm{NaHCO}_{3}$, and $0.1 \% \mathrm{BSA}, \mathrm{pH} 7.4$ ). The cells were resuspended in HBHS at a density of $5.6 \times 10^{6}$ cells $/ \mathrm{mL}$, and DNase I (Sigma-Aldrich) and cytochalasin B (Sigma-Aldrich) were each added at a final concentration of $5 \mu \mathrm{g} / \mathrm{mL}$. The cell suspension in each tube $\left(5.0 \times 10^{5}\right.$ cells $\left./ 90 \mu \mathrm{L}\right)$ was preincubated at $37^{\circ} \mathrm{C}$ for $10 \mathrm{~min}$ and stimulated with $10 \mu \mathrm{L}$ synthetic peptide solution at $37^{\circ} \mathrm{C}$ for $10 \mathrm{~min}$. The inhibitory effects of inhibitors against FPR1 [CysH (Sigma-Aldrich)] and FPR2 [PBP10 (Tocris Bioscience, Bristol, UK)] on $\beta$-hexosaminidase release induced by MCT-2 and its derivatives were also evaluated in the differentiated HL-60 cells; each cell suspension prepared as above $(90 \mu \mathrm{L})$ was transferred to a tube $\left(5.0 \times 10^{5}\right.$ cells/tube) with $5 \mu \mathrm{L}$ inhibitor solution for FPR1 (CysH) or FPR2 (PBP10). Each tube was then preincubated at $37^{\circ} \mathrm{C}$ for $10 \mathrm{~min}$ and stimulated with $5 \mu \mathrm{L}$ synthetic peptide solution at $37^{\circ} \mathrm{C}$ for $10 \mathrm{~min}$. After stimulation, $200 \mu \mathrm{L}$ ice-cold reaction quenching buffer ( $25 \mathrm{mM}$ Tris, $123 \mathrm{mM} \mathrm{NaCl}$, and $2.7 \mathrm{mM} \mathrm{KCl}, \mathrm{pH} 7.4$ ) was added to each cell suspension to stop the reaction. Thereafter, these tubes were centrifuged at $4{ }^{\circ} \mathrm{C}$ and $2300 \times g$ for $1 \mathrm{~min}$, and each supernatant was transferred into a new tube.

$\beta$-Hexosaminidase activity in the supernatant was measured as described previously [63]. Briefly, $90 \mu \mathrm{L}$ supernatant was transferred to each well of a 96-well microtiter plate, and $60 \mu \mathrm{L}$ of a substrate solution for $\beta$-hexosaminidase [10 mM p-nitrophenyl $\mathrm{N}$ - 
acetyl- $\beta$-D-glucosaminide (Sigma-Aldrich), $40 \mathrm{mM}$ citrate, and $70 \mathrm{mM} \mathrm{NaHPO} 4, \mathrm{pH} 4.5$ ] was added to initiate the enzyme reaction. After incubation of the plate at $37^{\circ} \mathrm{C}$ for $1 \mathrm{~h}$, $100 \mu \mathrm{L}$ of $400 \mathrm{mM}$ glycine ( $\mathrm{pH}$ 10.7) was added to stop the reaction. The absorbance at $415 \mathrm{~nm}$ for the resulting p-nitrophenol and at $490 \mathrm{~nm}$ for the reference was measured using a microtiter plate reader (Viento XS; BioTek Instruments, Winooski, VT, USA).

The ability of each peptide to induce $\beta$-hexosaminidase release was expressed as a percentage of enzyme secretion promoted by $10 \mu \mathrm{M}$ MCT-2(1-15) that induced the maximum response for the elucidation of full or partial agonists to the activity of MCT-2(1-15) (Figures 2 and 4, Table 2) or a percentage of the total enzyme activity, which was the enzyme activity released after disruption of the cells with $0.05 \%$ Triton X-100 (Figure 3).

\subsection{Measurement of Circular Dichroic Spectra}

CD spectra of the synthetic peptides were obtained at $25^{\circ} \mathrm{C}$ using a J-820 spectrometer (Jasco, Tokyo, Japan) in a quartz cell with a $0.1 \mathrm{~cm}$ path length. Spectra were collected between $190 \mathrm{~nm}$ and $250 \mathrm{~nm}$ with a scan speed of $50 \mathrm{~nm} / \mathrm{min}$, response time of $1 \mathrm{~s}$, and bandwidth of $1 \mathrm{~nm}$. Peptide samples with a final concentration of $100 \mu \mathrm{M}$ were prepared in $10 \mathrm{mM}$ phosphate buffer ( $\mathrm{pH} 7.4$ ) containing $0 \%$ or $50 \%$ TFE. The baseline scan, which was acquired by measuring the buffer alone, was subtracted from the experimental readings. CD data, which were collected every $1 \mathrm{~nm}$, were the average of 5 scans. The results were expressed as the optical rotation (mdeg).

\subsection{Analysis of Time-Dependent Alterations of MCT-2 Molecular Forms in Serum}

The animal experiments were conducted under the guidance of the Animal Care and Use Committee of the Nagahama Institute of Bio-Science and Technology (Approved No. 047). C57BL/6JJcl mice were purchased from Clea Japan (Tokyo, Japan). All mice were maintained in the Animal Research Facility at the Nagahama Institute of Bio-Science and Technology.

Male C57BL/6JJcl mice, 12-14 weeks of age, weighing 25-30 g, were anesthetized (50 mg/kg pentobarbital), and blood was collected from the caudal vena cava and stored overnight at $4{ }^{\circ} \mathrm{C}$. The blood sample was centrifuged at $4{ }^{\circ} \mathrm{C}$ and $20,000 \times g$ for $20 \mathrm{~min}$, and the supernatant was transferred to a new tube as mouse serum and stored at $-80{ }^{\circ} \mathrm{C}$. MCT-2(1-15) was incubated in mouse serum at a final concentration of $500 \mu \mathrm{M}$ at $37{ }^{\circ} \mathrm{C}$, and aliquots $(100 \mu \mathrm{L})$ were collected from the incubation mixture after $0,1,2,4,24$, and $48 \mathrm{~h}$. These aliquots were mixed with TCA (final concentration: 3\% $w / v$ ) and kept on ice for $30 \mathrm{~min}$ to precipitate denatured proteins. The samples were centrifuged at $4{ }^{\circ} \mathrm{C}$ and $13,000 \times g$ for $15 \mathrm{~min}$, and the supernatants were analyzed by RP-HPLC on a $\mathrm{C}_{18}$ column (4.6 × $150 \mathrm{~mm}$, Cosmosil; Nacalai Tesque, Inc.). RP-HPLC peaks that contained MCT-2(1-15) and its derivative peptides were analyzed by MALDI-TOF-MS to identify their molecular forms.

\subsection{Statistical Analysis}

Data are expressed as the mean \pm standard error (SE) in experiments containing multiple data points. Statistical comparisons between two groups were performed using Student's $t$-test, and values of $p<0.01$ were considered significant.

\section{Conclusions}

In the present study, we demonstrated that FPR2 recognizes the MCT-2(1-7) structure with an $\mathrm{N}$-formyl group for its specific activation to induce neutrophilic functions. $\mathrm{N}$-terminal MCT-2 derivatives shorter than seven amino acid residues were shown to lose their specificity for FPR2 and gain the ability to activate FPR1. Moreover, we showed that MCT-2(1-15) was degraded in serum over time, and the MCT-2-related FPR1 specific agonist MCT-2(1-4) was produced, suggesting that the receptor preference of MCT-2(1-15) in the bloodstream is shifted from FPR2 to FPR1 over time by the cleavage of its C-terminus by various proteases. Thus, MCT-2 is proposed to be a factor that controls not only the ini- 
tiation of innate immune responses against tissue injury, but also delayed responses via the activation of FPR1, which may relate to resolution and wound healing/tissue regeneration. In addition, because the docking simulation of MCT-2(1-15) and its derivatives to FPR1 or FPR2 well explained the receptor-specific activation mechanisms by those peptides as well as the results of structure-activity relationships, the present findings with structural information of FPR2 and FPR1 are expected to accelerate the development of specific antagonists for not only FPR2 but also FPR1 for the treatment of various inflammatory diseases including the recent epidemic of pneumonia that often causes multiple organ failure.

Supplementary Materials: The following are available online at https:/ /www.mdpi.com/article/10 .3390/ijms22084084/s1.

Author Contributions: Conceptualization, T.M. (Takayuki Marutani) and H.M.; methodology, T.M. (Takayuki Marutani), K.N. and H.M.; formal analysis, T.M. (Takayuki Marutani) and K.N.; investigation, T.M. (Takayuki Marutani), K.N., T.M. (Tomoyuki Miyaji), K.K. and K.O.; resources, T.M. (Takayuki Marutani), Y.K. and H.M.; data curation, T.M. (Takayuki Marutani) and H.M.; writingoriginal draft, T.M. (Takayuki Marutani) and H.M.; writing-review and editing, T.M. (Takayuki Marutani), Y.K. and H.M.; visualization, T.M. (Takayuki Marutani) and H.M.; supervision, H.M.; funding acquisition, T.M. (Takayuki Marutani), Y.K. and H.M. All authors have read and agreed to the published version of the manuscript.

Funding: This study was supported by research grants from the Ministry of Education, Culture, Sports, Science and Technology, Japan (Nos. 19K05853 and 17J11507), Nagase Science and Technology Foundation, and supplementary research aid from Maruhachi Muramatsu, Inc.

Institutional Review Board Statement: The present animal experiments were conducted under the guidance of Animal Care and Use Committee of the Nagahama Institute of Bio-Science and Technology (Approved No. 047).

Informed Consent Statement: Not applicable.

Data Availability Statement: All data and materials presented in this article and in the supplementary information are available from the corresponding author upon reasonable request.

Acknowledgments: The authors are grateful to Yasushi Kawai, Osamu Saitoh, and Shintaro Nomura for their critical reading of the manuscript and helpful advice. We also thank Masafumi Shionyu for helpful discussions and suggestions related to the docking between MCT-2 or its derivatives and FPR2 or FPR1.

Conflicts of Interest: The authors have no financial conflicts of interest to declare.

$\begin{array}{ll}\text { Abbreviations } \\ {\left[\mathrm{Ca}^{2+}\right]_{i}} & \text { Concentration of intracellular free } \mathrm{Ca}^{2+} \\ \mathrm{CD} & \text { Circular dichroic } \\ \mathrm{CysH} & \text { Cyclosporin } \mathrm{H} \\ \mathrm{EM} & \text { Electron microscopy } \\ \mathrm{fMLF} & \text { Formyl-Met-Leu-Phe } \\ \text { FPR1 } & \text { Formyl peptide receptor } 1 \\ \text { FPR2 } & \text { Formyl peptide receptor } 2 \\ \text { HBHS } & \text { HEPES-buffered Hank's solution } \\ \text { MCT-2 } & \text { Mitocryptide-2 } \\ \text { MS } & \text { Mass spectrometry } \\ \text { mtDAMPs } & \text { Mitochondrial damage-associated molecular patterns } \\ \text { RP } & \text { Reverse phase } \\ \text { TFE } & \text { 2,2,2-trifluoroethanol }\end{array}$

\section{References}

1. Springer, T.A. Traffic signals for lymphocyte recirculation and leukocyte emigration: The multistep paradigm. Cell 1994, 76, 301-314. [CrossRef]

2. Lay, K. Molecular mechanisms of leukocyte recruitment in the inflammatory process. Cardiovasc. Res. 1996, 32, 733-742. [CrossRef] 
3. Kolaczkowska, E.; Kubes, P. Neutrophil recruitment and function in health and inflammation. Nat. Rev. Immunol. 2013, 13, 159-175. [CrossRef] [PubMed]

4. Schiffmann, E.; Corcoran, B.A.; Wahl, S.M. N-formylmethionyl peptides as chemoattractants for leucocytes. Proc. Natl. Acad. Sci. USA 1975, 72, 1059-1062. [CrossRef]

5. Becker, E.L. The relationship of the chemotactic behavior of the complement-derived factors, C3a, C5a, and C567, and a bacterial chemotactic factor to their ability to activate the proesterase 1 of rabbit polymorphonuclear leukocytes. J. Exp. Med. 1972, 135, 376-387. [CrossRef] [PubMed]

6. Fernandez, H.N.; Henson, P.M.; Otani, A.; Hugli, T.E. Chemotactic response to human C3a and C5a anaphylatoxins. I. Evaluation of C3a and C5a leukotaxis in vitro and under stimulated in vivo conditions. J. Immunol. 1978, 120, $109-115$.

7. Marasco, W.A.; Phan, S.H.; Krutzsch, H.; Showell, H.J.; Feltner, D.E.; Nairn, R.; Becker, E.L.; Ward, P.A. Purification and identification of formyl-methionyl-leucyl-phenylalanine as the major peptide neutrophil chemotactic factor produced by Escherichia coli. J. Biol. Chem. 1984, 259, 5430-5439. [CrossRef]

8. Walz, A.; Peveri, P.; Aschauer, H.; Baggiolini, M. Purification and amino acid sequencing of NAF, a novel neutrophil-activating factor produced by monocytes. Biochem. Biophys. Res. Commun. 1987, 149, 755-761. [CrossRef]

9. Baggiolini, M.; Walz, A.; Kunkel, S.L. Neutrophil-activating peptide-1/interleukin 8, a novel cytokine that activates neutrophils. J. Clin. Investig. 1989, 84, 1045-1049. [CrossRef]

10. Ueki, N.; Someya, K.; Matsuo, Y.; Wakamatsu, K.; Mukai, H. Cryptides: Functional cryptic peptides hidden in protein structures. Biopolymers (Pep. Sci.) 2007, 88, 190-198. [CrossRef]

11. Mukai, H.; Hokari, Y.; Seki, T.; Takao, T.; Kubota, M.; Matsuo, Y.; Tsukagoshi, H.; Kato, M.; Kimura, H.; Shimonishi, Y.; et al. Discovery of mitocryptide-1, a neutrophil-activating cryptide from healthy porcine heart. J. Biol. Chem. 2008, 283 , 30596-30605. [CrossRef] [PubMed]

12. Mukai, H.; Seki, T.; Nakano, H.; Hokari, Y.; Takao, T.; Kawanami, M.; Tsukagoshi, H.; Kimura, H.; Kiso, Y.; Shimonishi, Y.; et al. Mitocryptide-2: Purification, identification, and characterization of a novel cryptide that activates neutrophils. J. Immunol. 2009, 182, 5072-5080. [CrossRef] [PubMed]

13. Hokari, Y.; Seki, T.; Nakano, H.; Matsuo, Y.; Fukamizu, A.; Munekata, E.; Kiso, Y.; Mukai, H. Isolation and identification of novel neutrophil-activating cryptides hidden in mitochondrial cytochrome c. Prot. Pept. Lett. 2012, 19, 680-687. [CrossRef]

14. Marutani, T.; Hattori, T.; Tsutsumi, K.; Koike, Y.; Harada, A.; Noguchi, K.; Kiso, Y.; Mukai, H. Mitochondrial protein-derived cryptides: Are endogenous N-formylated peptides including mitocryptide-2 components of mitochondrial damage-associated molecular patterns? Biopolymers (Pep. Sci.) 2016, 106, 580-587. [CrossRef]

15. Zhang, Q.; Raoof, M.; Chen, Y.; Sumi, Y.; Sursal, T.; Junger, W.; Brohi, K.; Itagaki, K.; Hauser, C.J. Circulating mitochondrial DAMPs cause inflammatory responses to injury. Nature 2010, 464, 104-107. [CrossRef]

16. McDonald, B.; Pittman, K.; Menezes, G.B.; Hirota, S.A.; Slaba, I.; Waterhouse, C.C.M.; Beck, P.L.; Muruve, D.A.; Kubes, P. Intravascular danger signals guide neutrophils to sites of sterile inflammation. Science 2010, 330, 362-366. [CrossRef]

17. Hauser, C.J.; Sursal, T.; Rodriguez, E.K.; Appleton, P.T.; Zhang, Q.; Itagaki, K. Mitochondrial DAMPs from femoral reamings activate neutrophils via formyl peptide receptors and P44/42 MAP kinase. J. Orthop. Trauma 2010, 24, 534-538. [CrossRef]

18. Maeda, A.; Fadeel, B. Mitochondria released by cells undergoing TNF- $\alpha$-induced necroptosis act as danger signals. Cell Death Dis. 2014, 5, e1312. [CrossRef]

19. $\mathrm{Hu}, \mathrm{Q} . ;$ Wood, C.R.; Cimen, S.; Venkatachalam, A.B.; Alwayn, I.P.J. Mitochondrial damage-associated molecular patterns (MTDs) are released during hepatic ischemia reperfusion and induce inflammatory responses. PLoS ONE 2015, 10, e0140105. [CrossRef]

20. Weinberg, S.E.; Sena, L.A.; Chandel, N. Mitochondria in the regulation of innate and adaptive immunity. Immunity 2015, 42, 406-417. [CrossRef]

21. Grazioli, S.; Pugin, J.N. Mitochondrial damage-associated molecular patterns: From inflammatory signaling to human diseases. Front. Immunol. 2018, 9, 832. [CrossRef] [PubMed]

22. Nakahira, K.; Kyung, S.Y.; Rogers, A.J.; Gazourian, L.; Youn, S.; Massaro, A.F.; Quintana, C.; Osorio, J.C.; Wang, Z.; Zhao, Y.; et al. Circulating mitochondrial DNA in patients in the ICU as a marker of mortality: Derivation and validation. PLoS Med. 2013, 10, e1001577. [CrossRef] [PubMed]

23. Unuma, K.; Aki, T.; Matsuda, S.; Funakoshi, T.; Yoshida, K.; Uemura, K. Elimination and active extrusion of liver mitochondrial proteins during lipopolysaccharide administration in rat. Hepatol. Res. 2013, 43, 526-534. [CrossRef] [PubMed]

24. Zhang, L.; Deng, S.; Zhao, S.; Ai, Y.; Zhang, L.; Pan, P.; Su, X.; Tan, H.; Wu, D. Intra-Peritoneal Administration of mitochondrial DNA provokes acute lung injury and systemic inflammation via toll-like receptor 9. Int. J. Mol. Sci. 2016, 17, 1425. [CrossRef]

25. Deng, S.Y.; Zhang, L.M.; Ai, Y.H.; Pan, P.H.; Zhao, S.P.; Su, X.L.; Wu, D.D.; Tan, H.Y.; Zhang, L.N.; Tsung, A. Role of interferon regulatory factor- 1 in lipopolysaccharide-induced mitochondrial damage and oxidative stress responses in macrophages. Int. J. Mol. Med. 2017, 40, 1261-1269. [CrossRef]

26. Podlesniy, P.; Figueiro-Silva, J.; Llado, A.; Antonell, A.; Sanchez-Valle, R.; Alcolea, D.; Lleo, A.; Molinuevo, J.L.; Serra, N.; Trullas, R. Low cerebrospinal fluid concentration of mitochondrial DNA in preclinical Alzheimer disease. Ann. Neurol. 2013, 74, 655-668. [CrossRef]

27. Wilkins, H.M.; Weidling, I.W.; Ji, Y.; Swerdlow, R.H. Mitochondria-derived damage-associated molecular patterns in neurodegeneration. Front. Immunol. 2017, 26, 508. [CrossRef] 
28. Hazeldine, J.; Hampson, P.; Opoku, F.A.; Foster, M.; Lord, J.M. N-Formyl peptides drive mitochondrial damage associated molecular pattern induced neutrophil activation through ERK1/2 and P38 MAP kinase signalling pathways. Injury 2015, 46, 975-984. [CrossRef]

29. Murphy, E.; Ardehali, H.; Balaban, R.S.; DiLisa, F.; Dorn, G.W., 2nd; Kitsis, R.N.; Otsu, K.; Ping, P.; Rizzuto, R.; Sack, M.N.; et al. Mitochondrial Function, Biology, and Role in Disease: A Scientific Statement From the American Heart Association. Circ. Res. 2016, 118, 1960-1991. [CrossRef]

30. Zhang, B.; Asadi, S.; Weng, Z.; Sismanopoulos, N.; Theoharides, T.C. Stimulated human mast cells secrete mitochondrial components that have autocrine and paracrine inflammatory actions. PLoS ONE 2012, 7, e49767. [CrossRef]

31. Walker, J.E.; Carroll, J.; Altman, M.C.; Fearnley, I.M. Mass spectrometric characterization of the thirteen subunits of bovine respiratory complexes that are encoded in mitochondrial DNA. Methods Enzymol. 2009, 456, 111-131.

32. Ott, M.; Amunts, A.; Brown, A. Organization and regulation of mitochondrial protein synthesis. Annu. Rev. Biochem. 2016, 85, 77-101. [CrossRef]

33. Boulay, F.; Tardif, M.; Brouchon, L.; Vignais, P. Synthesis and use of a novel N-formyl peptide derivative to isolate a human $\mathrm{N}$-formyl peptide receptor cDNA. Biochem. Biophys. Res. Commun. 1990, 168, 1103-1109. [CrossRef]

34. Quehenberger, O.; Prossnitz, E.R.; Cavanagh, S.L.; Cochrane, C.G.; Ye, R.D. Multiple domains of the N-formyl peptide receptor are required for high-affinity ligand binding. Construction and analysis of chimeric N-formyl peptide receptors. J. Biol. Chem. 1993, 268, 18167-18175. [CrossRef]

35. Murphy, P.M. The molecular biology of leukocyte chemoattractant receptors. Annu. Rev. Immunol. 1994, 12, 593-633. [CrossRef]

36. Seki, T.; Fukamizu, A.; Kiso, Y.; Mukai, H. Mitocryptide-2, a neutrophil-activating cryptide, is a specific endogenous agonist for formyl-peptide receptor-like 1. Biochem. Biophys. Res. Commun. 2011, 404, 482-487. [CrossRef] [PubMed]

37. Dahlgren, C.; Gabl, M.; Holdfeldt, A.; Winther, M.; Forsman, H. Basic characteristics of the neutrophil receptors that recognize formylated peptides, a danger-associated molecular pattern generated by bacteria and mitochondria. Biochem. Pharmacol. 2016, 114, 22-39. [CrossRef]

38. Weiß, E.; Kretschmer, D. Formyl-peptide receptors in infection, inflammation, and cancer. Trends Immunol. 2018, 39, 815-829. [CrossRef]

39. Wenceslau, C.F.; McCarthy, C.G.; Szasz, T.; Goulopoulou, S.; Webb, R.C. Mitochondrial N-formyl peptides induce cardiovascular collapse and sepsis-like syndrome. Am. J. Physiol. Heart Circ. Physiol. 2015, 308, H768-H777. [CrossRef]

40. Babbin, B.A.; Jesaitis, A.J.; Ivanov, A.I.; Kelly, D.; Laukoetter, M.; Nava, P.; Parkos, C.A.; Nusrat, A. Formyl peptide receptor-1 activation enhances intestinal epithelial cell restitution through phosphatidylinositol 3-kinase-dependent activation of Rac1 and Cdc42. J. Immunol. 2007, 179, 8112-8121. [CrossRef]

41. Zhang, X.G.; Hui, Y.N.; Huang, X.F.; Du, H.J.; Zhou, J.; Ma, J.X. Activation of formyl peptide receptor-1 enhances restitution of human retinal pigment epithelial cell monolayer under electric fields. Investig. Ophthalmol. Vis. Sci. 2011, 52, $3160-3165$. [CrossRef] [PubMed]

42. Shao, G.; Julian, M.W.; Bao, S.; McCullers, M.K.; Lai, J.P.; Knoell, D.L.; Crouser, E.D. Formyl peptide receptor ligands promote wound closure in lung epithelial cells. Am. J. Respir. Cell Mol. Biol. 2011, 44, 264-269. [CrossRef]

43. Liu, M.; Chen, K.; Yoshimura, T.; Liu, Y.; Gong, W.; Le, Y.; Gao, J.L.; Zhao, J.; Wang, J.M.; Wang, A. Formylpeptide receptors mediate rapid neutrophil mobilization to accelerate wound healing. PLoS ONE 2014, 9, e90613. [CrossRef] [PubMed]

44. Zhang, L.; Wang, H.; Yang, T.; Su, Z.; Fang, D.; Wang, Y.; Fang, J.; Hou, X.; Le, Y.; Chen, K.; et al. Formylpeptide receptor 1 mediates the tumorigenicity of human hepatocellular carcinoma cells. Oncoimmunology 2015, 5, e1078055. [CrossRef] [PubMed]

45. Lind, S.; Gabl, M.; Holdfeldt, A.; Mårtensson, J.; Sundqvist, M.; Nishino, K.; Dahlgren, C.; Mukai, H.; Forsman, H. Identification of residues critical for FPR2 activation by the cryptic peptide mitocryptide-2 originating from the mitochondrial DNA-encoded cytochrome b. J. Immunol. 2019, 202, 2710-2719. [CrossRef]

46. Gabl, M.; Sundqvist, M.; Holdfeldt, A.; Lind, S.; Mårtensson, J.; Christenson, K.; Marutani, T.; Dahlgren, C.; Mukai, H.; Forsman, H. Mitocryptides from human mitochondrial DNA-encoded proteins activate neutrophil formyl peptide receptors: Receptor preference and signaling properties. J. Immunol. 2018, 200, 3269-3282. [CrossRef]

47. Offermanns, S.; Simon, M.I. G $\alpha_{15}$ and $\mathrm{G} \alpha_{16}$ couple a wide variety of receptors to phospholipase C. J. Biol. Chem. 1995, 270, 15175-15180. [CrossRef]

48. Williams, L.T.; Snyderman, R.; Pike, M.C.; Lefkowitz, R.J. Specific receptor sites for chemotactic peptides on human polymorphonuclear leukocytes. Proc. Natl. Acad. Sci. USA 1977, 74, 1204-1208. [CrossRef]

49. Niedel, J.; Kahane, I.; Lachman, L.; Cuatrecasas, P. A subpopulation of cultured human promyelocytic leukemia cells (HL-60) displays the formyl peptide chemotactic receptor. Proc. Natl. Acad. Sci. USA 1980, 77, 1000-1004. [CrossRef]

50. Chaplinski, T.J.; Niedel, J.E. Cyclic nucleotide-induced maturation of human promyelocytic leukemia cells. J. Clin. Investig. 1982, 70, 953-964. [CrossRef]

51. Krautwurst, D.; Seifert, R.; Hescheler, J.; Schultz, G. Formyl peptides and ATP stimulate $\mathrm{Ca}^{2+}$ and $\mathrm{Na}^{+}$inward currents through non-selective cation channels via G-proteins in dibutyryl cyclic AMP-differentiated HL-60 cells. Involvement of $\mathrm{Ca}^{2+}$ and $\mathrm{Na}^{+}$in the activation of $\beta$-glucuronidase release and superoxide production. Biochem. J. 1992, 288, 1025-1035.

52. Gysin, B.; Schwyzer, R. Hydrophobic and electrostatic interactions between adrenocorticotropin-(1-24)-tetracosapeptide and lipid vesicles. amphiphilic primary structures. Biochemistry 1984, 23, 1811-1818. [CrossRef] 
53. Sargent, D.F.; Schwyzer, R. Membrane lipid phase as catalyst for peptide-receptor interactions. Proc. Natl. Acad. Sci. USA 1986, 83, 5774-5778. [CrossRef]

54. Zhuang, Y.; Liu, H.; Edward Zhou, X.; Verma, K.R.; de Waal, P.W.; Jang, W.; Xu, T.H.; Wang, L.; Meng, X.; Zhao, G.; et al. Structure of formylpeptide receptor $2-G_{i}$ complex reveals insights into ligand recognition and signaling. Nat. Commun. 2020, 11, 885. [CrossRef]

55. Dufton, N.; Hannon, R.; Brancaleone, V.; Dalli, J.; Patel, H.B.; Gray, M.; D’Acquisto, F.; Buckingham, J.C.; Perretti, M.; Flower, R.J. Anti-inflammatory role of the murine formyl-peptide receptor 2: Ligand-specific effects on leukocyte responses and experimental inflammation. J. Immunol. 2010, 184, 2611-2619. [CrossRef]

56. Kim, S.D.; Kim, Y.K.; Lee, H.Y.; Kim, Y.S.; Jeon, S.G.; Baek, S.H.; Song, D.K.; Ryu, S.H.; Bae, Y.S. The agonists of formyl peptide receptors prevent development of severe sepsis after microbial infection. J. Immunol. 2010, 185, 4302-4310. [CrossRef] [PubMed]

57. Kim, S.D.; Kwon, S.; Lee, S.K.; Kook, M.; Lee, H.Y.; Song, K.D.; Lee, H.K.; Baek, S.H.; Park, C.B.; Bae, Y.S. The immune-stimulating peptide WKYMVm has therapeutic effects against ulcerative colitis. Exp. Mol. Med. 2013, 45, e40. [CrossRef] [PubMed]

58. Kim, Y.E.; Park, W.S.; Ahn, S.Y.; Sung, D.K.; Sung, S.I.; Kim, J.H.; Chang, Y.S. WKYMVm hexapeptide, a strong formyl peptide receptor 2 agonist, attenuates hyperoxia-induced lung injuries in newborn mice. Sci. Rep. 2019, 9, 6815. [CrossRef] [PubMed]

59. Merrifield, R.B. Solid phase peptide synthesis. I. The synthesis of a tetrapeptide. J. Am. Chem. Soc. 1963, 85, 2149-2154. [CrossRef]

60. Mukai, H.; Kawai, K.; Suzuki, Y.; Yamashita, K.; Munekata, E. Stimulation of dog gastropancreatic hormone release by neuromedin B and its analogues. Am. J. Physiol. 1987, 252, E765-E771. [CrossRef]

61. Mukai, H.; Munekata, E.; Higashijima, T. G protein antagonist. A novel hydrophobic peptide competes with receptor for G protein binding. J. Biol. Chem. 1992, 267, 16237-16243. [CrossRef]

62. Mukai, H.; Kikuchi, M.; Suzuki, Y.; Munekata, E. A mastoparan analog without lytic effects and its stimulatory mechanisms in mast cells. Biochem. Biophys. Res. Commun. 2007, 362, 51-55. [CrossRef] [PubMed]

63. Nakajima, T.; Wakamatsu, K.; Mukai, H. Mastoparan as a G protein-activator. In Methods and Tools in Biosciences and Medicine: Animal Toxins; Birkhauser: Basel, Switzerland, 2000; pp. 116-126. 